Trinity University

Digital Commons @ Trinity

$5-2021$

\title{
A Modeling Study of the Mobilization and Sequestration of Trace Metals in a Crude-Oil-Contaminated Aquifer
}

Zoe M. Lacey

Trinity University, zoelacey99@gmail.com

Follow this and additional works at: https://digitalcommons.trinity.edu/geo_honors

\section{Recommended Citation}

Lacey, Zoe M., "A Modeling Study of the Mobilization and Sequestration of Trace Metals in a Crude-OilContaminated Aquifer" (2021). Geosciences Student Honors Theses. 22.

https://digitalcommons.trinity.edu/geo_honors/22

This Thesis open access is brought to you for free and open access by the Geosciences Department at Digital Commons@ @rinity. It has been accepted for inclusion in Geosciences Student Honors Theses by an authorized administrator of Digital Commons @ Trinity. For more information, please contact jcostanz@trinity.edu. 
A MODELING STUDY OF THE MOBILIZATION AND SEQUESTRATION OF TRACE METALS IN A CRUDE-OIL- CONTAMINATED AQUIFER

ZOE M. LACEY

A DEPARTMENT HONORS THESIS SUBMITTED TO THE DEPARTMENT OF GEOSCIENCES AT TRINITY UNIVERSITY

IN PARTIAL FULFILLMENT OF THE REQUIREMENTS FOR GRADUATION WITH DEPARTMENTAL HONORS

APRIL 23, 2020

BRADY A. ZIEGLER

THESIS ADVISOR
KATHLEEN D. SURPLESS

DEPARTMENT CHAIR

\section{Michael Soto, AVPAA}




\section{Student Agreement}

I grant Trinity University ("Institution"), my academic department ("Department"), and the Texas Digital Library ("TDL") the non-exclusive rights to copy, display, perform, distribute and publish the content I submit to this repository (hereafter called "Work") and to make the Work available in any format in perpetuity as part of a TDL, digital preservation program, Institution or Department repository communication, distribution or preservation effort.

I understand that once the Work is submitted, a bibliographic citation to the Work can remain visible in perpetuity, even if the Work is updated or removed.

I understand that the Work's copyright owner(s) will continue to own copyright outside these non-exclusive granted rights.

I warrant that:

1) I am the copyright owner of the Work, or

2) I am one of the copyright owners and have permission from the other owners to submit the Work, or

3) My Institution or Department is the copyright owner and I have permission to submit the Work, or

4) Another party is the copyright owner and I have permission to submit the Work.

Based on this, I further warrant to my knowledge:

1) The Work does not infringe any copyright, patent, or trade secrets of any third party,

2) The Work does not contain any libelous matter, nor invade the privacy of any person or third party, and

3) That no right in the Work has been sold, mortgaged, or otherwise disposed of, and is free from all claims.

I agree to hold TDL, Institution, Department, and their agents harmless for any liability arising from any breach of the above warranties or any claim of intellectual property infringement arising from the exercise of these non-exclusive granted rights.

I choose the following option for sharing my thesis (required):

[X] Open Access (full-text discoverable via search engines)

[ ] Restricted to campus viewing only (allow access only on the Trinity University campus via

digitalcommons.trinity.edu)

I choose to append the following Creative Commons license (optional): 


\section{Abstract}

Using a reactive transport model, I simulated the mobilization and sequestration of geogenic trace metals, nickel $\left(\mathrm{Ni}^{2+}\right)$ and cobalt $\left(\mathrm{Co}^{2+}\right)$, in a crude-oil-contaminated aquifer. These trace metals can pose threats to human and ecological health and are not commonly regulated or measured at oil-spill sites, making it important to characterize the geochemical mechanisms that release and attenuate potentially toxic trace metals. In the groundwater-contaminant plume, crude-oil is biodegraded coupled to iron (Fe(III)) reduction and methanogenesis. Previously collected field data ${ }^{1}$ showed concentrations of $\mathrm{Ni}^{2+}$, and $\mathrm{Co}^{2+}$ near the crude-oil source were elevated in groundwater and depleted from aquifer sediments compared to background concentrations. Roughly 80 meters downgradient, in the active Fe(III)-reducing zone, groundwater concentrations of $\mathrm{Ni}^{2+}$ and $\mathrm{Co}^{2+}$ decrease, relative to near the crude-oil body, and concentrations in sediment increase above background levels. Using a reactive transport model, I show that $\mathrm{Ni}^{2+}$ and $\mathrm{Co}^{2+}$ originally sorbed to $\mathrm{Fe}(\mathrm{III})$ are released from sediments near the oil body due to microbially mediated Fe(III)-reduction to aqueous $\mathrm{Fe}^{2+}$. Biodegradation in the active $\mathrm{Fe}(\mathrm{III})$-reducing zone, dissolves $\mathrm{Fe}^{2+}$ and produces bicarbonate, causing groundwater supersaturation with respect to siderite $\left(\mathrm{FeCO}_{3}\right)$, allowing $\mathrm{FeCO}_{3}$ to precipitate. I developed a surface complexation model for $\mathrm{Ni}^{2+}$ and $\mathrm{Co}^{2+}$ on $\mathrm{FeCO}_{3}$, to incorporate into our reactive transport model framework. Our modeling results showed that $\mathrm{FeCO}_{3}$ generates negative surface charge in the $\mathrm{pH}$ range measured in the contaminant plume (6.3-7.3), allowing $\mathrm{FeCO}_{3}$ to sorb $\mathrm{Ni}^{2+}$ and $\mathrm{Co}^{2+}$ and remove them from groundwater. Our modeling results were consistent with field observations. Previous sampling has shown that arsenic (As), which also is mobilized due to $\mathrm{Fe}(\mathrm{III})$ reduction, does not accumulate in Fe-reducing sediments like $\mathrm{Ni}^{2+}$ and $\mathrm{Co}^{2+}$. The negative surface charge on $\mathrm{FeCO}_{3}$ favors sorption of cations $\left(\mathrm{Ni}^{2+}\right.$ and $\left.\mathrm{Co}^{2+}\right)$ but not the (oxy)anions of As. Our model effectively delineated mechanisms that could release and attenuate trace metals at oil-spill sites, which can aid in more comprehensive predictions of threats to human and ecological health in aquifers contaminated by crude-oil. 


\section{Introduction}

\subsection{Background}

Geogenic trace elements that originate in the aquifer solids are the most common type of groundwater contaminant ${ }^{2}$. Trace elements can contaminate groundwater through multiple mechanisms including reductive dissolution ${ }^{3-5}$, acid-base-promoted desorption ${ }^{6,7}$, sulfide oxidation $^{8-10}$, and geothermal activity ${ }^{11,12}$, among others ${ }^{13}$. A common mechanism for trace element release is reductive dissolution of ferric iron (Fe(III))-containing minerals with trace elements sorbed to them. In the presence of organic matter in anoxic groundwater, organic carbon can be biodegraded (i.e., oxidized) coupled with the reduction of Fe(III) in the mineral to Fe(II), which is soluble in groundwater as the $\mathrm{Fe}^{2+} \mathrm{ion}^{14-16}$. This mechanism has been observed in sewage $^{17}$, landfill ${ }^{18}$, crude-oil ${ }^{14-16}$, and petroleum/ethanol ${ }^{19}$ contaminant plumes, and can occur with natural organic matter, resulting in widespread trace element contamination of groundwater, that can have implications for both environmental and human health ${ }^{13,20,21}$.

Recent studies of a crude-oil-contaminated aquifer undergoing natural attenuation have documented numerous secondary water quality impacts, including plumes of various mobilized trace elements. For example, arsenic (As) $)^{14-16}$ sorbed to Fe(III) hydroxides has been mobilized into groundwater where biodegradation is coupled with Fe(III)-reduction ${ }^{13,14}$. Follow-up field studies of the crude-oil-contaminated aquifer have found additional trace element plumes of nickel $\left(\mathrm{Ni}^{2+}\right)$, cobalt $\left(\mathrm{Co}^{2+}\right)$, strontium $\left(\mathrm{Sr}^{2+}\right)$, barium $\left(\mathrm{Ba}^{2+}\right)$, and chromium $(\mathrm{Cr})^{1,19}$.

Despite this aquifer being intensively studied over the past $35+$ years, the phenomenon of trace element mobilization was only discovered in the past several years. While crude-oil chemicals pose their own water quality impairments, the mobilization of trace elements introduces additional water quality impairments with unique implications for human and environmental health. Some of 
these trace elements are regulated at the national level by the United States Environmental Protection Agency (EPA) (e.g., As) or recommended for regulation by the World Health Organization (WHO) (e.g., barium $\left(\mathrm{Ba}^{2+}\right)$ and nickel $\left.\left(\mathrm{Ni}^{2+}\right)\right)$ because of their link to adverse health outcomes. Toxic outcomes of barium exposure include cardiac and renal failure, and gastrointestinal problems ${ }^{20}$. Toxic outcomes of $\mathrm{Ni}^{2+}$ exposure include possible skin irritation ${ }^{21}$. Arsenic has been linked to multiple types of cancer ${ }^{20-22}$. Cobalt $\left(\mathrm{Co}^{2+}\right)$ is not currently regulated by the EPA but is under consideration through the EPA Contaminant Candidate List due to possible public health concerns related to its presence in public water supply ${ }^{23}$.The negative health effects associated with these trace elements warrant more studies on the behavior of these geogenic elements in groundwater once mobilized.

This study uses a reactive transport model to elucidate mechanisms of trace element mobilization and sequestration in a crude-oil-contaminated aquifer near Bemidji, Minnesota. Natural attenuation, primarily driven by biodegradation, has altered the geochemistry of this aquifer ${ }^{24}$ and introduced geogenic $\mathrm{Ni}^{2+}$ and $\mathrm{Co}^{2+}$ into groundwater of the contaminant plume. The goal in modeling the fate and transport of $\mathrm{Ni}^{2+}$ and $\mathrm{Co}^{2+}$ is to explore the related geochemical processes that can alter aquifer geochemistry. Changes to aquifer geochemistry can have adverse effects on environmental and human health making it pertinent to better understand mechanisms that are able to alter water quality.

\subsection{Study Site}

The aquifer at the Bemidji crude-oil contaminant site is a glacial outwash aquifer located within the Pleistocene Bagley Outwash Plain which consists primarily of a pitted sand and gravel outwash $^{25}$. The aquifer is unconfined; the contaminated portion of the aquifer consists of moderately calcareous silty sand overlying clayey till with interbedded discontinuous silt layers 
interbedded with sand ${ }^{25}$. The sand fraction of sediment is approximately $60 \%$ quartz, $5 \%$ carbonates, $30 \%$ feldspars, and 5\% heavy minerals; the silt fraction has a higher abundance of carbonate when compared to the bulk sediment ${ }^{25}$. Groundwater velocities were determined to range from 0.15 to 0.5 meters per day using the point dilution method for Darcy velocity ${ }^{25}$.

In 1979 a crude oil pipeline ruptured, releasing 10,700 barrels of oil onto the land surface near Bemidji, Minnesota. Of the total oil spilled, 2600 barrels percolated through the unsaturated zone and accumulated on the water table ${ }^{26}$. The oil body sitting on the water table acts as a source of dissolved organic carbon as the soluble and partially soluble crude-oil constituents from the oil body dissolve into groundwater to form a hydrocarbon contaminant plume. The plume stimulates microbial activity, that result in depleted dissolved oxygen due to aerobic respiration. This creates anoxic conditions, in which hydrocarbon biodegradation is then coupled to anaerobic terminal electron accepting processes (TEAPs) ${ }^{14}$. Fe(III)-reduction and methanogenesis are the primary TEAPS that facilitate biodegradation in the crude-oil plume ${ }^{14}$. The various TEAPs seen in the aquifer result in four distinct geochemical zones: the methanogenic zone near the crude-oil body, the anoxic Fe-reducing zone, the suboxic transition zone at the leading edge of the contaminant plume and on the plume fringes, and the uncontaminated, oxic background waters (Figure 1B) ${ }^{14}$. Since 1983, the Bemidji oil spill site has been a national research site through the U.S. Geological Survey (USGS) Toxic Substances Hydrology Program to study long-term natural attenuation of oil spills. Since then, decades of research have focused on this crude-oil contaminated aquifer to study the hydrogeology and biogeochemical processes which affect the aquifer. See Essaid et al. ${ }^{27}$ for a summary of previous work ${ }^{24,25,27-29}$.

Previous field studies have shown that groundwater in the crude-oil plume has elevated concentrations of $\mathrm{Ni}^{2+}, \mathrm{Co}^{2+}$, and As, among other trace elements. Each element has its own 
individual "plume", the spatial extents of which is controlled by unique biogeochemical processes in the aquifer ${ }^{1,14}$. For example, an As plume extends from the oil body to roughly $130 \mathrm{~m}$ downgradient from well 421 , this well is the reference datum demarcating the approximate center of the crude-oil body floating on the water table. Around $130 \mathrm{~m}$, As is attenuated by sorbing to Fehydroxides in sediment, effectively remediating the As plume. Plumes of $\mathrm{Ni}^{2+}$ and $\mathrm{Co}^{2+}$, in contrast, are attenuated by accumulating in sediment closer to the oil body, around $40 \mathrm{~m}$ downgradient from well 421. The difference in attenuation patterns between $\mathrm{As}$ and $\mathrm{Co}^{2+} / \mathrm{Ni}^{2+}$ suggest that transport of these different trace elements is controlled by different geochemical processes.

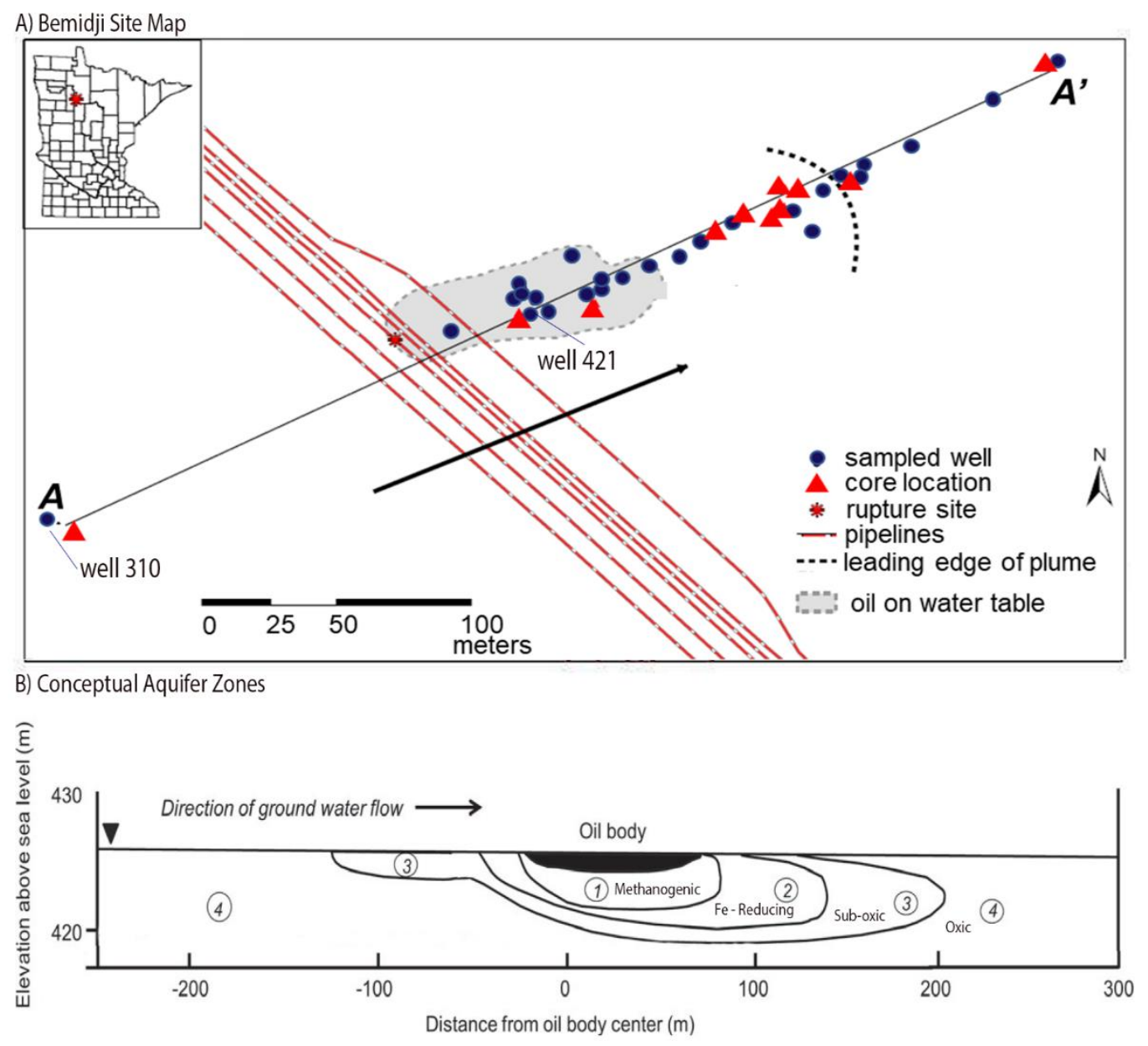


Figure 1. A) Map of the Bemidji contaminated aquifer along the center-line transect (A-A') of the oil plume adapted from Jones ${ }^{1}$. The map shows wells and sediment core locations where field data were collected and reported elsewhere ${ }^{1,15,16,30}$, the rupture site, the pipelines, the leading edge of the plume, and crude oil floating on the water table. The inset shows the location of the spill within Minnesota. B) Conceptual diagram of geochemical zones in the aquifer, adapted from Cozzarelli et al. ${ }^{14}$. Zone 1 is methanogenic, zone 2 is Fe-reducing, zone 3 is sub-oxic, and zone 4 is oxic.

\section{Methods}

In this study, I expand upon a reactive transport model previously developed by $\mathrm{Ng}$ et al. ${ }^{29}$ which took a comprehensive approach to modeling the processes occurring in the Bemidji aquifer known at the time of its development. The model incorporates biodegradation of organics coupled to multiple TEAPs ${ }^{24,31-35}$, direct outgassing of $\mathrm{CH}_{4}$ and $\mathrm{CO}_{2}$, dissolution of $\mathrm{CO}_{2}$, and sorption of reduced $\mathrm{Fe}^{2+29}$. Later, the model was expanded upon to include new information about As cycling in the aquifer ${ }^{15}$. Now, I further expand upon this robust model to reflect new data about trace element cation cycling in the aquifer initially described by Jones ${ }^{1}$. The model now includes an expanded surface complexation model to describe $\mathrm{Ni}^{2+}$ and $\mathrm{Co}^{2+}$ sorption and desorption with respect to two sorbent phases, siderite $\left(\mathrm{FeCO}_{3}\right)$ and the $\mathrm{Fe}(\mathrm{III})$ hydroxide $\mathrm{Fe}(\mathrm{OH})_{3}$, in an attempt to simulate the geochemical mechanism(s) responsible for mobilization and attenuation of geogenic trace elements in the contaminant plume. The model used PHT3D ${ }^{36}$, which combines geochemical reactions from PHREEQC $-2^{37}$, groundwater flow from MODFLOW-2005 $5^{38}$, and solute transport from MT3DMS ${ }^{39}$ (Figure 2). 


\subsection{Model domain and hydrogeologic parameters}

A conceptual diagram of the model is shown in Figure 2. The original hydrogeologic parameters and model domain from the $\mathrm{Ng}$ et al. ${ }^{29}$ model were used in this model. The simulation began with the oil-spill occurring in August 1979 and covered 15,000 days (through September 2020) (Figure 2). The model analysis domain depicts a two-dimensional cross-section of the groundwater plume, with each cell in the computational grid having dimensions of $4.3 \mathrm{~m}$ horizontally by $0.47 \mathrm{~m}$ vertically. The domain extends horizontally from $45 \mathrm{~m}$ upgradient to $215 \mathrm{~m}$ downgradient from the center of the oil body and vertically from 417 to $424 \mathrm{~m}$ above mean sea level. The computational grid extends to $475 \mathrm{~m}$ downgradient from the oil body and an elevation of $410 \mathrm{~m}$ to avoid boundary effects during model simulations. The upper boundary of the model domain is the water table.

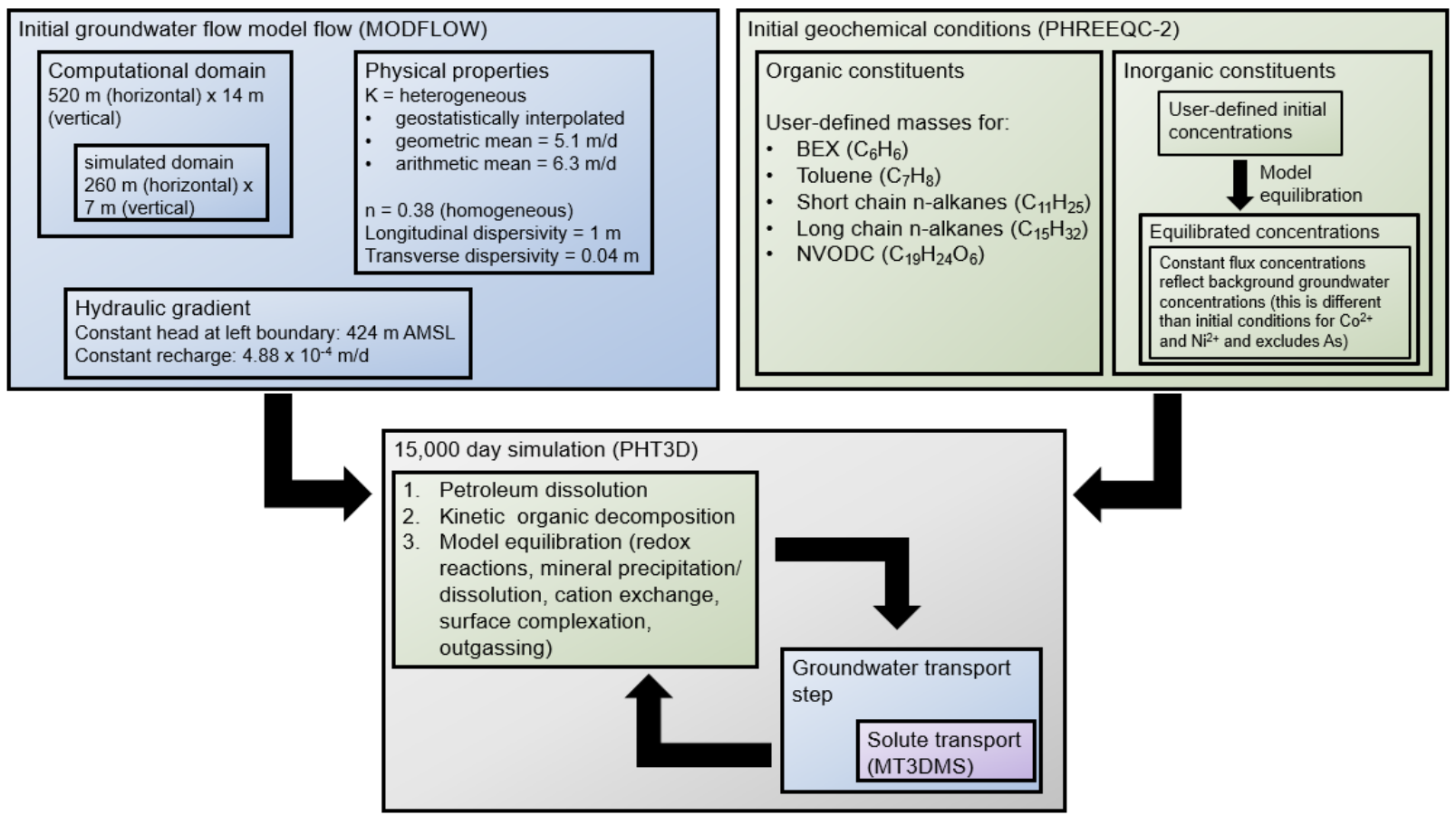


Figure 2. Model Conceptual Diagram. The top left blue box illustrates the components of the initial groundwater flow model (MODFLOW-2005). The top right green box illustrates components of the initial geochemical conditions (PHREEQC-2). The bottom grey box illustrates the simulation steps performed by PHT3D that incorporate both geochemical reactions performed by PHREEQC-2, groundwater transport performed by MODFLOW-2005, and solute transport performed by MT3DMS.

A porosity of 0.38 was chosen based on grain size analyses reported in Dillard et al. ${ }^{40}$ and assigned homogeneously to the model due to the low variability ( \pm 0.04$)$ amongst the 269 samples. Hydraulic conductivity $(\mathrm{K})$ in the aquifer was determined based on 58 slug tests performed in different wells in the aquifer. Slug test results showed that $\mathrm{K}$ ranged from $10^{-3}$ to $10 \mathrm{~m} / \mathrm{d}$ with a median of $6.3 \mathrm{~m} / \mathrm{d}^{41}$. K was applied heterogeneously to the model with geometric $(5.1 \mathrm{~m} / \mathrm{d})$ and arithmetic $(6.3 \mathrm{~m} / \mathrm{d})$ means based on geostatistical interpolations of the grain size analyses from sediment collected from the study site $^{40}$ and then inflated for a closer match to the homogeneous $6.1 \mathrm{~m} / \mathrm{d}$ determined by Essaid et al. ${ }^{32}$ (Figure 2).Longitudinal $(1 \mathrm{~m})$ and transverse $(0.04 \mathrm{~m})$ dispersivities based on a field tracer test, were applied uniformly to the model domain ${ }^{32}$. To produce the observed average hydraulic gradient (0.0035), a steady state flow field was imposed by applying a constant head boundary of $424 \mathrm{~m}$ above sea level at the left boundary with a constant recharge rate of $4.88 \times 10^{-4} \mathrm{~m} / \mathrm{d}$ (Figure 2) as determined by inverse modeling ${ }^{32}$. Partial oil saturation is achieved through a relative water permeability while the oil phase is modeled as stationary in time. 


\subsection{Geochemical formulation}

Modeled aqueous inorganic species include inorganic $\mathrm{C}, \mathrm{CH}_{4}$, dissolved oxygen (DO), $\mathrm{Mn}, \mathrm{Fe}$, $\mathrm{Ca}, \mathrm{Cl}, \mathrm{Na}, \mathrm{H}$, inert N, As(III), As(V), Co, and Ni. Pyrolusite $\left(\mathrm{MnO}_{2}\right)$, amorphous ferric hydroxide $\left(\mathrm{Fe}(\mathrm{OH})_{3}\right)$, rhodochrosite $\left(\mathrm{MnCO}_{3}\right)$, and siderite $\left(\mathrm{FeCO}_{3}\right)$ are allowed to precipitate because they act as mineral sinks for elevated $\mathrm{Fe}^{2+}$ and $\mathrm{Mn}^{2+}$ in groundwater due to biodegradation. Calcite is included due to its role in carbonate chemistry. Species sorbed via cation exchange (HX, FeX 2 and $\mathrm{MnX}_{2}$ ) and surface complexes for $\mathrm{Co}^{2+}, \mathrm{Ni}^{2+}, \mathrm{As}(\mathrm{V})$ (arsenate), $\mathrm{As}(\mathrm{III})$ (arsenite), and $\mathrm{HCO}_{3}{ }^{-}$are included in the model. Dissolved gas phases $\left(\mathrm{CO}_{2}, \mathrm{CH}_{4}, \mathrm{O}_{2}\right.$, and inert $\left.\mathrm{N}_{2}\right)$ are used to simulate outgassing. For equilibrium reactions, with the exception of $\mathrm{Fe}(\mathrm{OH})_{3}$ and $\mathrm{FeCO}_{3}, \log \mathrm{K}$ values from the default PHREEQC database were used. Values of equilibrium constants for $\mathrm{Fe}(\mathrm{OH})_{3}$ and $\mathrm{FeCO}_{3}$ dissolution and cation exchange were calibrated by $\mathrm{Ng}$ et al. ${ }^{29}$.

Organic carbon degradation is modeled for four oil constituents: BEX (benzene, ethylbenzene, and xylenes, all modeled as one component), toluene, long- and short-chain $n$-alkanes, and oil constituents contributing to non-volatile dissolved organic carbon (NVDOC) (Figure 2). The degradation processes were determined based on dissolution pathways, biodegradation pathways, and oil loss pathways described in detail by $\mathrm{Ng}$ et al. ${ }^{28}$. Briefly, the dissolution and biodegradation rate parameters were calibrated based on field data from $1979^{28,29,32,42-45}, 1987 \pm 2^{24,25,42}, 1993$ $\pm 2^{28,45,46}$, and $2008 \pm 2^{28,42,43,47-52}$. Unique dissolution rates and first-order biodegradation rates under different TEAPs were assigned to each constituent. BEX is assumed to follow a multicomponent dissolution rate while $n$-alkane oxidation has kinetic rates set explicitly for methanogenic biodegradation.

A partial equilibrium approach ${ }^{53}$ was used for the geochemical model. This approach assumes that the organic carbon oxidation step is the rate-limiting step, and the associated reduction step 
proceeds as an equilibrium reaction. This is accomplished using PHT3D by irreversibly breaking down an organic molecule at a specific rate into its constitutive elements and valence states. The reactions and first-order rate constants for the oxidation of the four organic constituents are reported in Table 1.

Table 1. Kinetic biodegradation reactions and first-order rate coefficients

\begin{tabular}{ll} 
Kinetic reactions & First-order rate coefficient $\left(\mathrm{s}^{-1}\right)$ \\
\hline $\begin{array}{l}\mathrm{BEX} \\
\quad \mathrm{C}_{6} \mathrm{H}_{6} \rightarrow 6 \mathrm{C}(-1)+6 \mathrm{H}(+1)\end{array}$ & $1.00 \times 10^{-8}$ \\
Toluene & $3.50 \times 10^{-9}$ \\
$\quad \mathrm{C}_{7} \mathrm{H}_{8} \rightarrow 7 \mathrm{C}(-1)+8 \mathrm{H}(+1)$ & \\
$\mathrm{NVDOC}$ & $1.47 \times 10^{-8}$ \\
$\quad \mathrm{C}_{19} \mathrm{H}_{24} \mathrm{O}_{6} \rightarrow 19 \mathrm{C}(-1)+24 \mathrm{H}(+1)+6 \mathrm{O}(-2)$ & \\
short chain n-alkanes & $7.60 \times 10^{-10}$ \\
$\quad \mathrm{C}_{11} \mathrm{H}_{25} \rightarrow 11 \mathrm{C}(-1)+25 \mathrm{H}(+1)$ & $1.10 \times 10^{-9}$ \\
long chain n-alkanes & $\mathrm{C}_{15} \mathrm{H}_{32} \rightarrow 15 \mathrm{C}(-1)+32 \mathrm{H}(+1)$
\end{tabular}

The constitutive elements are then reintroduced into the equilibrium model, where $\mathrm{C}(-1)$ is then converted to the inorganic carbon form (i.e., $\mathrm{HCO}_{3}^{-}$) via the most thermodynamically favorable TEAP based on the model chemistry (Table 2). Note that coefficients a, b, and $c$ in Table 2 are determined by the kinetic oxidation of hydrocarbons (Table 1), and the consequent stoichiometry is then necessarily dependent upon coefficients $\mathrm{a}, \mathrm{b}$, and $\mathrm{c}$ for a given reaction. Reactions proceed sequentially from aerobic respiration to manganese reduction, followed by iron reduction and methanogenesis. Note that if a hydrocarbon undergoing oxidation does not contain oxygen (e.g., $\mathrm{C}_{6} \mathrm{H}_{6}$ ), coefficient $\mathrm{c}$ in Table 2 reactions would be zero, removing it from the reaction. 
Table 2. Thermodynamic redox reaction stoichiometry

Aerobic respiration

$$
a \mathrm{C}(-1)+b \mathrm{H}(+1)+c \mathrm{O}(-2)+1.25 a \mathrm{O}_{2}+0.5(a-c) \mathrm{H}_{2} \mathrm{O} \rightarrow a \mathrm{HCO}_{3}{ }^{-}+(b-2 a) \mathrm{H}^{+}
$$

Manganese reduction

$$
a \mathrm{C}(-1)+b \mathrm{H}(+1)+c \mathrm{O}(-2)+2.5 a \mathrm{MnO}_{2}+(5 a+2 c-b) \mathrm{H}^{+} \rightarrow a \mathrm{HCO}_{3}{ }^{-}+(2 a+c) \mathrm{H}_{2} \mathrm{O}
$$

Iron reduction

$$
a \mathrm{C}(-1)+b \mathrm{H}(+1)+c \mathrm{O}(-2)+5 a \mathrm{Fe}(\mathrm{OH})_{3}+(5 a+2 c-b) \mathrm{H}^{+} \rightarrow a \mathrm{HCO}_{3}{ }^{-}+(12 a+c) \mathrm{H}_{2} \mathrm{O}
$$

Methanogenesis

$$
a \mathrm{C}(-1)+b \mathrm{H}(+1)+c \mathrm{O}(-2)+(3 d-c) \mathrm{H}^{+} \rightarrow d \mathrm{HCO}_{3}{ }^{-}+(b+d-2 c-4 a) \mathrm{H}_{2} \mathrm{O}
$$

Surface complexation on $\mathrm{Fe}(\mathrm{OH})_{3}$ was modeled using the generalized two-layer model and database described in Dzombak and Morel $^{54}$. The two-layer model defines "Type 1" and "Type 2" sites, also referred to as strong and weak sites, respectively. $\mathrm{Fe}(\mathrm{OH})_{3}$ strong sites are defined in the PHREEQC database as Hfo_s, where "s" identifies strong sites that correspond to a small subset of surface sites with high affinity for cation sorption. Type 2 sites defined in the PHREEQC database as Hfo_w, where "w" identifies weak sites which correspond to the total reactive sites available for sorption of protons, cations, and anions to $\mathrm{Fe}(\mathrm{OH})_{3}$ as determined by observed sorption maxima ${ }^{54}$. Initial simulations accounted for $\mathrm{Co}^{2+}$ sorption reactions to both strong and weak sites, and strong sites were more favored to the point where weak sites did not make a significant impact comparatively. $\mathrm{Ni}^{2+}$ sorption reactions were modeled only to strong sites as Dzombak and Morel $^{54}$ did not report a $\log \mathrm{K}$ for a weak site sorption reaction and strong site sorption tends to be more favorable for cations. Arsenic (as oxyanions) and $\mathrm{HCO}_{3}^{-}$sorption reactions were modeled using only weak sites, as strong sites are cation-specific. $\mathrm{Fe}(\mathrm{OH})_{3}$ sorption constants where based on values from Dzombak and Morel $^{54}$ and then calibrated within the model. 
The specific surface area $\left(600 \mathrm{~m}^{2} / \mathrm{g}\right)$ and surface site density for Hfo_s $(0.006 \mathrm{~mol} / \mathrm{mol} \mathrm{Fe})($ Table 3) were taken from the Dzombak and $\mathrm{Morel}^{54}$ database.

Sorption onto $\mathrm{FeCO}_{3}$ was modeled using a one-site surface complexation model similar to that explained by Tahervand and Jalali ${ }^{55}$. Binding sites were described by surface complexation reactions combined with surface characteristics such as specific surface area and site density.

$\mathrm{Guo}^{56}$ found a range of values for the surface area $\left(6.8-8.5 \mathrm{~m}^{2} / \mathrm{g}\right)$ of a sample comprised of $96 \% \mathrm{FeCO}_{3}$. Because the $\mathrm{FeCO}_{3}$ precipitated in the aquifer is likely highly amorphous, I used the value on the high end of the range from $\mathrm{Guo}^{56}\left(8.5 \mathrm{~m}^{2} / \mathrm{g}\right){ }^{56}$ and doubled it in the model to a value of $17 \mathrm{~m}^{2} / \mathrm{g}$ of $\mathrm{FeCO}_{3}$ (Table 3) to better approximate the high ratio of surface area to volume of amorphous $\mathrm{FeCO}_{3}$. The site density reported by Van Cappellen et al. ${ }^{57}$ of $18 \mu \mathrm{mol}$ sites $/ \mathrm{m}^{2}$ surface area $\mathrm{FeCO}_{3}{ }^{57}$ combined with the assumption that carbonate surface sites $\left(>\mathrm{CO}_{3}\right)$ make up half of the sites and result in a surface site density of $9 \mu \mathrm{mol}>\mathrm{CO}_{3}$ sites $/ \mathrm{m}^{2}$ surface area $\mathrm{FeCO}_{3}$. To achieve similar concentrations and patterns of $\mathrm{Ni}^{2+}$ and $\mathrm{Co}^{2+}$ sorbed to $\mathrm{FeCO}_{3}$ and to reflect the amorphous nature of $\mathrm{FeCO}_{3}$, the surface site density was doubled to $18 \mu \mathrm{mol}>\mathrm{CO}_{3}$ sites $/ \mathrm{m}^{2}$ surface area $\mathrm{FeCO}_{3}$ (Table 3).

Current research of carbonate surface complexation has been done in a limited capacity using laboratory experiments and has mainly focused on homogeneous systems (e.g., Mn sorbed to $\mathrm{MnCO}_{3}$, Fe sorbed to $\left.\mathrm{FeCO}_{3}\right)$. The exception to this is calcite $\left(\mathrm{CaCO}_{3}\right)$, which has been studied in greater detail. Sorption of various cations including $\mathrm{Ba}^{2+}, \mathrm{Sr}^{2+}, \mathrm{Cd}^{2+}, \mathrm{Mn}^{2+}, \mathrm{Zn}^{2+}, \mathrm{Co}^{2+}$, and $\mathrm{Ni}^{2+}$ to calcite is described by Zachara et al. ${ }^{58}$. To my knowledge, $\operatorname{logK}$ values for sorption of $\mathrm{Co}^{2+}$ and $\mathrm{Ni}^{2+}$ to siderite do not exist in the literature. Therefore, I assumed that $\log \mathrm{K}$ values for sorption to calcite would serve as reasonable initial estimates given the similar mineralogy between calcite and siderite. Thus, $\log \mathrm{K}$ values for $\mathrm{Co}^{2+}$ and $\mathrm{Ni}^{2+}$ sorption to calcite from Zachara et al. ${ }^{58}$ were put 
into the model as proxies and then calibrated in the model based on field data from Jones ${ }^{1}$ to better reflect sorption parameters onto $\mathrm{FeCO}_{3}$.

Modeled output $\mathrm{Ni}^{2+}$ and $\mathrm{Co}^{2+}$ concentrations were constrained by new and archival groundwater and sediment chemistry data compiled by Jones ${ }^{1}$, while also honoring previously documented patterns of $\mathrm{DO}, \mathrm{pH}, \mathrm{Fe}, \mathrm{NVDOC}$, and $\mathrm{BEX}$ constrained by groundwater and sediment chemistry data collected in 1987,1993 , and $2008^{28}$. DO, pH, and Fe were further constrained by 2011-2015 data $^{14,15,16}$.

Table 3. Sorption Parameters and Reactions

Site Density Parameters

$\mathrm{Fe}(\mathrm{OH})_{3}$

$\mathrm{FeCO}_{3}$

Surface Area Parameters

$\mathrm{Fe}(\mathrm{OH})_{3}$

$\mathrm{FeCO}_{3}$
Rxn. $\quad \mathrm{SidH}=\mathrm{Sid}^{-}+\mathrm{H}^{+}$

5

\section{Ni 2+ reactions}

Rxn. $\quad \mathrm{Sid}^{-}+\mathrm{Ni}^{2+}=\mathrm{SidNi}^{+}$

6
Site density

$6 \frac{\mu \mathrm{mol}>\mathrm{OH}_{3} \text { sites }}{\mathrm{m}^{2} \text { surface area }}$

$18 \frac{\mu \mathrm{mol}>\mathrm{CO}_{3} \text { sites }}{\mathrm{m}^{2} \text { surface area }}$

Surface Area

$600\left(\frac{m^{2}}{g \mathrm{Fe}(\mathrm{OH})_{3}}\right)$

$17 \frac{m^{2}}{\mathrm{gFeCO}_{3}}$

$\log \mathrm{K}$

$$
\log \mathrm{K}^{-} 95 \%
$$

C.I. ${ }^{b}$

$-4.4$

Ref.

ref. C.I. ${ }^{c}$ 
Rxn. Hfo_sOH $+\mathrm{Ni}^{2+}=\mathrm{Hfo} \_\mathrm{sONi}+\mathrm{H}^{+} \quad 1.5$

7

Co 2+ surface reactions

Rxn. $\quad \mathrm{Sid}^{-}+\mathrm{Co}^{2+}=\mathrm{SidCo}^{+} \quad-1.5$

8

Rxn. Hfo_sOH $+\mathrm{Co}^{2+}=\mathrm{Hfo} \_s O C o+\mathrm{H}^{+} \quad 1.6$

9

Rxn. Hfo_wOH $+\mathrm{Co}^{2+}=\mathrm{Hfo} \_\mathrm{wOCO}^{+}+-3.01$

$10 \quad \mathrm{H}^{+}$

Arsenate $(\mathrm{As}(\mathrm{V}))$ reaction

Rxn. Hfo_wOH $+\mathrm{AsO}_{4}{ }^{3-}+3 \mathrm{H}^{+}=$

28.29

30.34

(a)

11 Hfo_w $\mathrm{w}_{2} \mathrm{AsO}_{4}+\mathrm{H}_{2} \mathrm{O}$

Rxn. Hfo_wOH $+\mathrm{AsO}_{4}{ }^{3-}+2 \mathrm{H}^{+}=$

23.51

23.33

23.7

(a)

12 Hfo_wHAsO ${ }_{4}^{-}+\mathrm{H}_{2} \mathrm{O}$

18.1

(e)

13 Hfo_wAsO ${ }_{4}^{2-}+\mathrm{H}_{2} \mathrm{O}$

Rxn. $\mathrm{Hfo} \_\mathrm{wOH}+\mathrm{AsO}_{4}{ }^{3-}=$

14 Hfo_wOHAsO ${ }_{4}^{3-}$

$10.58 \quad 10.01$

11.15

(a)

Arsenite (As(III)) reactions

Rxn. Hfo_wOH $+\mathrm{H}_{3} \mathrm{AsO}_{3}=$

15 Hfo_w $\mathrm{H}_{2} \mathrm{AsO}_{3}+\mathrm{H}_{2} \mathrm{O}$

5.71

(a)

Bicarbonate reaction

Rxn. Hfo_wOH $+\mathrm{CO}_{3}{ }^{2-}+2 \mathrm{H}^{+}=$

$20.37 \quad 19.39$

21.35

16 Hfo_w $\mathrm{HCO}_{3}+\mathrm{H}_{2} \mathrm{O}$

Rxn. Hfo_wOH $+\mathrm{CO}_{3}{ }^{2-}+\mathrm{H}^{+}=$

12.78

12.58

12.98

(f)

17 Hfo_wCO ${ }_{3}^{-}+\mathrm{H}_{2} \mathrm{O}$

18

Rxn. $\mathrm{H}_{2} \mathrm{AsO}_{4}{ }^{-}=\mathrm{HAsO}_{4}{ }^{2-}+\mathrm{H}^{+}$

6.96

19

11.5

(d)

20

Rxn. $\mathrm{H}_{3} \mathrm{AsO}_{3}=\mathrm{H}_{2} \mathrm{AsO}_{3}{ }^{-}+\mathrm{H}^{+}$

9.29 
${ }^{a}$ Acidity constants correspond to $\mathrm{T}=20-25{ }^{\circ} \mathrm{C}$ and $\mathrm{I}=0$.

${ }^{b}$ Lower $95 \%$ confidence interval for $\log \mathrm{K}$ value

${ }^{c}$ Upper $95 \%$ confidence interval for $\log \mathrm{K}$ value

a. Dzombak and Morel (1990)

b. Calibrated based on Van Capellen (1993)

c. Calibrated based on Guo (2007)

d. Smith and Martell (1976)

e. Dixit and Hering (2003)

f. Appelo et al. (2002)

g. Calibrated based on calcium carbonate sorption LogK's in Zachara et al (1990)

\subsection{Initial Conditions}

Initial parameters for organic $\mathrm{C}$ constituents, initial total $\mathrm{C}$ mass, and mass fractions of BEX, toluene, NVDOC, short-chain $n$-alkanes, and long chain $n$-alkanes are from $\mathrm{Ng}$ et $\mathrm{al}^{29}$. Initial concentrations for dissolved constituents (total carbonates, $\mathrm{CH}_{4}, \mathrm{Ca}^{2+}, \mathrm{Cl}^{-}, \mathrm{Fe}^{2+}, \mathrm{Mg}^{2+}, \mathrm{Na}^{+}, \mathrm{DO}$, $\mathrm{Mn}^{2+}, \mathrm{N}_{2}, \mathrm{pH}$ ) were determined based on data from six sampling periods between 1986 and 1995 of an uncontaminated background well upgradient from the spill site (well 310E in Figure 1), these concentrations are also representative of modern-day background concentrations. Concentrations from these sampling periods were averaged and then equilibrated with calcite and charge-balanced using PHREEQC-2. Concentrations for initial model input of aqueous $\mathrm{Ni}^{2+}$ and $\mathrm{Co}^{2+}$ remained the same after equilibration at $5.2209 \times 10^{-9} \mathrm{~mol} / \mathrm{L}$ and $4.968 \times 10^{-10} \mathrm{~mol} / \mathrm{L}$, respectively. The left boundary and water table boundary are constant concentration flux boundaries with the initial solution chemistry except $\mathrm{Ni}^{2+}$ and $\mathrm{Co}^{2+}$ which use recharge concentrations equivalent to background conditions that differ from calibrated initial conditions. Arsenic is not included in recharge solution chemistry at the boundaries because it is below detection $(<1 \mu \mathrm{g} / \mathrm{L})$ in background groundwater. 
Initial $\mathrm{Fe}(\mathrm{OH})_{3}$ concentrations were based on the average of background sample measurements using a $0.5 \mathrm{M} \mathrm{HCl}$ extraction method ${ }^{45}$ and assuming a bulk density of $1650 \mathrm{~g} / \mathrm{L}$. The extraction method used targets operationally defined "easily reducible" $\mathrm{Fe}(\mathrm{III}){ }^{45}$ that is then characterized in the model as $\mathrm{Fe}(\mathrm{OH})_{3}$. The concentration of reducible $\mathrm{Fe}(\mathrm{III})$ was determined by comparing the amount of $\mathrm{Fe}(\mathrm{III})$ extracted from uncontaminated background sediment to the amount of $\mathrm{Fe}(\mathrm{III})$ extracted from sediment just downgradient from the oil body in the contaminant plume. Near the oil body, Fe-reduction has occurred for several years following the spill prior to turning methanogenic after the bioavailable Fe(III) had been depleted. Extraction results showed low amounts of HCl-extractable Fe(III) remain in the sediment near the crude-oil body despite redox conditions being methanogenic, indicating that not all $\mathrm{Fe}(\mathrm{III})$ in the sediment may be easily reducible by microbes ${ }^{16}$. Thus, the difference between Fe(III) concentrations in uncontaminated background sediment and sediment near the crude-oil body was used to constrain the initial $\mathrm{Fe}(\mathrm{OH})_{3}$ concentration of $0.0288 \mathrm{~mol} / \mathrm{L}_{\mathrm{v}}\left(\mathrm{L}_{\mathrm{v}}\right.$ is bulk or total aquifer volume- solids plus pore space- in liters). Similarly, initial concentrations of $\mathrm{Ni}^{2+}$ and $\mathrm{Co}^{2+}$ sorbed to $\mathrm{Fe}(\mathrm{OH})_{3}$ were constrained by the difference between the background concentrations and residual concentrations near the crude-oil body. Thus, the model represents the concentration of $\mathrm{Ni}^{2+}$ and $\mathrm{Co}^{2+}$ made available through biodegradation.

The surface complexation model for $\mathrm{Ni}^{2+}$ and $\mathrm{Co}^{2+}$ was equilibrated with the dissolved concentrations in the initial solution to approximate observed concentrations of $\mathrm{Ni}^{2+}$ and $\mathrm{Co}^{2+}$ sorbed to $\mathrm{Fe}(\mathrm{OH})_{3}{ }^{1}$. The initial concentrations of dissolved $\mathrm{Ni}^{2+}$ and $\mathrm{Co}^{2+}$ were calibrated to best match concentrations of $\mathrm{Ni}^{2+}$ and $\mathrm{Co}^{2+}$ in groundwater and sediment while remaining close to background concentrations at 15,000 days to be $5.2209 \times 10^{-9} \mathrm{~mol} / \mathrm{L}$ and $4.968 \times 10^{-10} \mathrm{~mol} / \mathrm{L}$ respectively. The groundwater concentration of $\mathrm{Ni}^{2+}$ and $\mathrm{Co}^{2+}$ for recharge was set to groundwater 
background levels of $5.6209 \times 10^{-9} \mathrm{~mol} / \mathrm{L}$ and $1.6968 \times 10^{-9} \mathrm{~mol} / \mathrm{L}$ respectively, as reported by Jones ${ }^{1}$. After equilibration, concentrations of $\mathrm{Ni}^{2+}$ and $\mathrm{Co}^{2+}$ sorbed to $\mathrm{Fe}(\mathrm{OH})_{3}$ where 0.023 $\mathrm{mmol} / \mathrm{L}_{\mathrm{v}}$ and $0.0027 \mathrm{mmol} / \mathrm{L}_{\mathrm{v}}$ respectively. Background conditions for $\mathrm{Ni}^{2+}$ and $\mathrm{Co}^{2+}$ in sediment from field data are $0.07 \mathrm{mmol} / \mathrm{L}_{\mathrm{v}}$ and $0.013 \mathrm{mmol} / \mathrm{L}_{\mathrm{v}}$ respectively. Because background groundwater is undersaturated with respect to $\mathrm{FeCO}_{3}, \mathrm{FeCO}_{3}$ does not form in background sediment in the model, and thus there are no $\mathrm{Ni}^{2+}$ or $\mathrm{Co}^{2+}$ complexes on $\mathrm{FeCO}_{3}$ as an initial condition.

\subsection{Calibration Approach}

The model in this study was calibrated so that patterns of $\mathrm{Ni}^{2+}$ and $\mathrm{Co}^{2+}$ concentrations in the sediment and groundwater were similar to that of the field data collected from $2010-2019^{1}$; it also honors the spatial concentration patterns of $\mathrm{DO}, \mathrm{pH}, \mathrm{Fe}^{2+}, \mathrm{CH}_{4}, \mathrm{Fe}(\mathrm{OH})_{3}$, and $\mathrm{FeCO}_{3}$ observed in $1987,1999,2008$, and 2015, which were accounted for in previous versions of this model ${ }^{19,29}$. Given that all these parameters are interdependent upon one another in the equilibrium model, I recognized that concessions regarding spatial patterns of trace elements and simulated concentrations would have to be made to honor the collective processes occurring in the model plume. As such, I decided that simulated concentrations within one order of magnitude of the measured concentrations in the field would constitute an "accurate" model. While I attempt to accurately simulate spatial distribution and concentration of $\mathrm{Ni}^{2+}$ and $\mathrm{Co}^{2+}$ in both groundwater and sediment, a general replication of the spatial distributions was accepted because concentrations can fluctuate in individual wells with no reflection of geochemical processes in the aquifer due to well construction ${ }^{59-61}$ and the purging/sampling procedures ${ }^{62}$ used. Thus, comparing point-to-point concentrations for calibration is likely overly prescriptive to gaining insight into the 
biogeochemical reactions that affect the mobilization and attenuation of $\mathrm{Ni}^{2+}$ and $\mathrm{Co}^{2+}$ in a contaminated aquifer.

\section{Results}

\subsection{Aquifer Chemistry from Biodegradation}

In this paper, I report modeled concentrations 15,000 days after the oil spill for $\mathrm{DO}, \mathrm{Fe}^{2+}, \mathrm{HCO}_{3}{ }^{-}$ , $\mathrm{CH}_{4}$ and $\mathrm{pH}$, as they are relevant to the geochemical processes controlling trace element cycling. Other species were included in the simulation but have little relevance to the cycling of trace elements, so their values are not reported here.

Early aerobic biodegradation of the crude-oil results in depleted DO levels near the oil body (Figure 3.A) and thus allows for the onset of anaerobic biodegradation, namely biodegradation coupled with Fe-reduction and methanogenesis. During Fe-reduction, $\mathrm{Fe}(\mathrm{OH})_{3}$ is reductively dissolved and releases $\mathrm{Fe}^{2+}$ into groundwater creating a plume of elevated $\mathrm{Fe}^{2+}$ concentrations (Figure 3.E). After the reservoir of $\mathrm{Fe}(\mathrm{OH})_{3}$ has been depleted near the oil body due to $\mathrm{Fe}-$ reduction, biodegradation proceeds by methanogenesis, resulting in a plume of elevated dissolved $\mathrm{CH}_{4}$ concentrations (Figure 3.B). During all biodegradation reactions, organic $\mathrm{C}$ is mineralized to produce high concentrations of $\mathrm{HCO}_{3}^{-}$(Table 2). Further downgradient from the methanogenic zone, where $\mathrm{Fe}(\mathrm{OH})_{3}$ reduction is the dominant TEAP ( $\sim 100 \mathrm{~m}$ downgradient $)$, elevated dissolved $\mathrm{Fe}^{2+}$ combined with elevated $\mathrm{HCO}_{3}{ }^{-}$cause groundwater supersaturation with respect to siderite $\left(\mathrm{FeCO}_{3}\right)$, causing it to precipitate with the highest concentrations from $50-100 \mathrm{~m}$ downgradient from well 421 (Figure 3.F)(Eq. 1).

$$
\mathrm{Fe}^{2+}+\mathrm{HCO}_{3}^{-}=\mathrm{Fe}^{2+}+\mathrm{CO}_{3}{ }^{2-}+\mathrm{H}^{+}=\mathrm{FeCO}_{3}+\mathrm{H}^{+}
$$


Multiple reactions, including siderite formation, are $\mathrm{pH}$-dependent, so a discussion of the controls on $\mathrm{pH}$ is warranted. Near the oil body, field data have shown abundant non-carbonate $\mathrm{Fe}(\mathrm{II})$ in the sediment. This, combined with low $\mathrm{pH}$ as seen in field data ${ }^{1}$, leads to the use of cation exchange in the model to allow for partially immobilized $\mathrm{Fe}(\mathrm{II})$ to appear as $\mathrm{FeX}_{2}{ }^{29}$, which produces acidity as a byproduct (Eq. 2).

$$
2 \mathrm{HX}+\mathrm{Fe}^{2+}=\mathrm{FeX}_{2}+2 \mathrm{H}^{+}
$$

$\mathrm{H}^{+}$is a reaction byproduct of methanogenesis (Table 2), a primary TEAP near to the oil body. Combined, methanogenesis and cation exchange explain the lower $\mathrm{pH}$ observed $-25-100 \mathrm{~m}$ downgradient from well 421 (Figure 3.D). Further downgradient in the Fe-reducing zone, $\mathrm{H}^{+}$is consumed as a reactant during Fe-reduction (Table 2), leading to an overall increase in $\mathrm{pH}$ as a result of the reaction. Lower $\mathrm{pH}$ (i.e., elevated concentrations of $\mathrm{H}^{+}$) thermodynamically disfavors the formation of $\mathrm{FeCO}_{3}$ near the oil, as $\mathrm{H}^{+}$is a product of siderite precipitation from $\mathrm{Fe}^{2+}$ and $\mathrm{HCO}_{3}^{-}$(Eq.1). Despite the higher concentrations of $\mathrm{Fe}^{2+}$ (Figure 3.E) and $\mathrm{HCO}_{3}^{-}$(Figure 3.G) closer to the oil, the higher concentrations of $\mathrm{H}^{+}$in this zone thermodynamically limit siderite from forming. This results in the highest siderite concentrations in the Fe-reducing zone (Figure 3.F), even though $\mathrm{Fe}^{2+}$ and $\mathrm{HCO}_{3}{ }^{-}$concentrations are comparatively lower in groundwater in this zone.

Last, the resulting $\mathrm{pH}$ controls the surface charge on the two sorbent phases, $\mathrm{Fe}(\mathrm{OH})_{3}$ and $\mathrm{FeCO}_{3}$, and thus controls their ability to sorb oppositely charged ions in solution. From Table 3, the $\mathrm{pK}_{\mathrm{a} 1}$ and $\mathrm{pK}_{\mathrm{a} 2}$ for $\mathrm{Fe}(\mathrm{OH})_{3}$ are 7.29 and $8.93^{54}$, respectively, meaning that below $\mathrm{pH} 7.29$, the dominant surface charge will be positive, between $\mathrm{pH} 7.29$ and 8.29 the dominant surface charge will be neutral, and above $\mathrm{pH} 8.29$, the dominant surface charge will be negative. However, it is 
important to note that between $\mathrm{pH} 7.29$ and 8.29 , small fractions of both positive and negative surface species exist ${ }^{63}$, allowing for surface complexation of both cations and anions simultaneously. From Table 3, the $\mathrm{pK}_{\mathrm{a}}$ for $\mathrm{FeCO}_{3}$ is 4.4 meaning that below $\mathrm{pH} 4.4$ the dominant surface charge will be neutral and above $\mathrm{pH} 4.4$ the dominant surface charge will be negative ${ }^{57}$. Near the oil body where methanogenic conditions dominate, $\mathrm{pH}$ is lower $(\sim 6.6)$ than background conditions (Figure 3.D). Under these conditions, $\mathrm{Fe}(\mathrm{OH})_{3}$ would generate mostly positively charged surface sites, favoring anion sorption and disfavor sorption of trace element cations. Conversely, $\mathrm{FeCO}_{3}$ would generate a negative surface charge, allowing it to sorb cations. Further downgradient in the Fe-reducing zone, $\mathrm{pH}$ is $\sim 6.9-7.3$, indicating that the majority of $\mathrm{Fe}(\mathrm{OH})_{3}$ surface sites would be positively charged and favor anion sorption, though some surface sites can be negatively charged and sorb cations. $\mathrm{FeCO}_{3}$ surface sites would be negatively charged and favor cation sorption. 

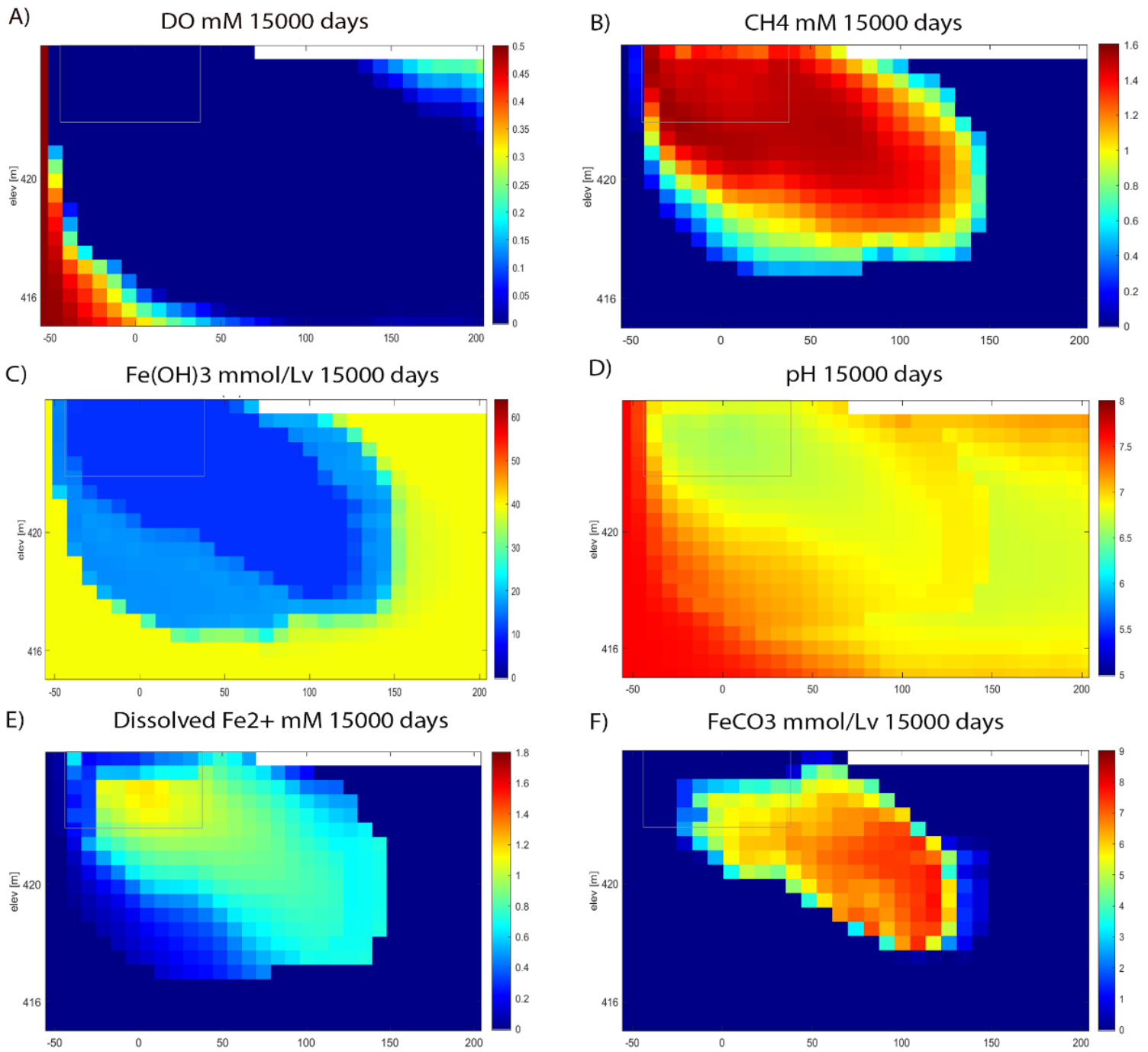

G) $\quad \mathrm{HCO} 3 \mathrm{mM} 15000$ days

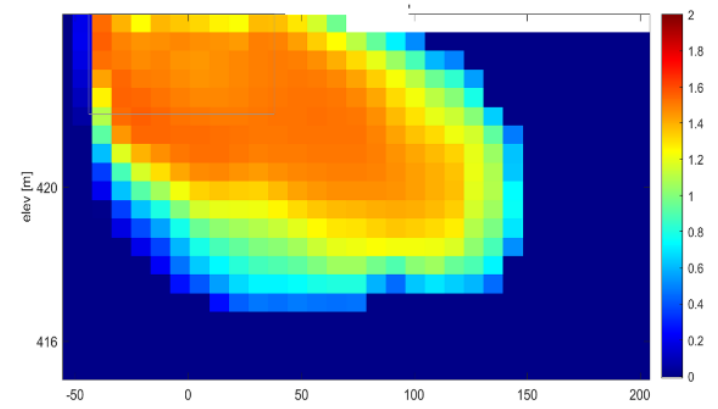

Figure 3. Aquifer chemistry related to biodegradation processes 15,000 days after the oil spill. Constituents include A) dissolved oxygen $(\mathrm{mM})$, B) $\left.\mathrm{CH}_{4}(\mathrm{mM}), \mathrm{C}\right) \mathrm{Fe}(\mathrm{OH})_{3}$ in sediment $\left.\left.\left(\mathrm{mmol} / \mathrm{L}_{\mathrm{v}}\right), \mathrm{D}\right) \mathrm{pH}, \mathrm{E}\right)$ aqueous $\left.\mathrm{Fe}^{2+}(\mathrm{mM}), \mathrm{F}\right) \mathrm{FeCO}_{3}$ in sediment $\left(\mathrm{mmol} / \mathrm{L}_{\mathrm{v}}\right)$. 


\subsection{Mobilization and Attenuation of $\mathrm{Ni}^{2+}$ and $\mathrm{Co}^{2+}$}

Here I present results of aqueous and sorbed (to $\mathrm{Fe}(\mathrm{OH})_{3}$ and $\mathrm{FeCO}_{3}$ ) $\mathrm{Ni}^{2+}$ and $\mathrm{Co}^{2+}$ phases from the model and compare them to concentrations measured in groundwater and aquifer sediments reported by Jones ${ }^{1}$. Interpolated field data of sediment from Jones ${ }^{1}$ represents bulk sediment data (Figure 4.A; 5.A), that includes both available (i.e., mobilizable due to biodegradation processes) and non-available (i.e., $\mathrm{Ni}$ and $\mathrm{Co}$ remaining in sediment for $\sim 40$ years after the spill) $\mathrm{Ni}$ and $\mathrm{Co}$ in the sediment. Since this residual Ni and Co remain in sediment $\sim 40$ years after the spill, I assumed they are likely part of a more recalcitrant mineral phase that is not influenced by biodegradation processes in the plume. Therefore, to make more accurate comparisons of available $\mathrm{Ni}$ and $\mathrm{Co}$ and model results, the residual concentrations of $\mathrm{Ni}$ and $\mathrm{Co}$ in sediment near the oil body were subtracted from bulk $\mathrm{Ni}$ and Co sediment concentrations in the model domain, resulting in the amount of "available" $\mathrm{Ni}$ and $\mathrm{Co}$ in sediment that can be mobilized during biodegradation processes (Figure 4B; 5B). These resulting residual-subtraction concentrations of $\mathrm{Ni}$ and Co where then used for comparison to the model. It is important to note that the residual-subtraction plots do not specify any specific retention mechanism or phase. In order to illustrate the roles of sorption on $\mathrm{FeCO}_{3}$ and $\mathrm{Fe}(\mathrm{OH})_{3}$ individually, the model produces a plot indicating $\mathrm{Ni}$ and Co sorbed to $\mathrm{FeCO}_{3}$ and a separate plot indicating $\mathrm{Ni}$ and $\mathrm{Co}$ sorbed to $\mathrm{Fe}(\mathrm{OH})_{3}$. The true "total" $\mathrm{Ni}$ and $\mathrm{Co}$ in sediment in a model cell would be the sum of the metals sorbed to $\mathrm{FeCO}_{3}$ and the metals sorbed to $\mathrm{Fe}(\mathrm{OH})_{3}$, though no cell appears to have appreciable amounts of metals simultaneously sorbed to both minerals, as the two minerals are stable under opposing redox conditions.

Near the crude-oil body, $\mathrm{Ni}^{2+}$ and $\mathrm{Co}^{2+}$ are depleted in the sediment for two reasons. First, methanogenesis is the primary TEAP because a majority of the available Fe(III) had been reduced in the past, when Fe-reduction was the dominant TEAP in this zone ${ }^{30} \cdot \mathrm{Ni}^{2+}$ and $\mathrm{Co}^{2+}$, which were 
originally sorbed to $\mathrm{Fe}(\mathrm{OH})_{3}$ in sediments, were mobilized into groundwater as the hydroxides dissolved. This is reflected by increased concentrations of aqueous $\mathrm{Ni}^{2+}$ and $\mathrm{Co}^{2+}$ near the oil body (Figure 6). Second, as methanogenic conditions became predominant, and $\mathrm{Fe}^{2+}$ exchanged with $\mathrm{H}^{+}$in sediment, groundwater $\mathrm{pH}$ decreased to values that generate only positive surface charge on $\mathrm{Fe}(\mathrm{OH})_{3}$ based on the $\mathrm{pK}_{\mathrm{a} 1}$ value of 7.29. Although there is some residual $\mathrm{Fe}(\mathrm{OH})_{3}$ near the oil body (Figure 3.C), the surface sites would electrostatically repulse positively charged $\mathrm{Ni}^{2+}$ and $\mathrm{Co}^{2+}$, causing them to desorb into groundwater and create their respective plumes.

In the model, the center of mass in the $\mathrm{Ni}^{2+}$ groundwater plume is near $50 \mathrm{~m}$ downgradient from well 421 and at an elevation of $421 \mathrm{~m}$ AMSL with a maximum concentration of $0.0025 \mathrm{mmol} / \mathrm{L}$ (Figure 6.B). Field data show the center of mass in the $\mathrm{Ni}^{2+}$ groundwater plume is closer to $25 \mathrm{~m}$ downgradient from well 421 and at an elevation of $422 \mathrm{~m}$ AMSL with a maximum concentration of $0.002 \mathrm{mmol} / \mathrm{L}^{1}$ (Figure 3.A). The center of mass in the $\mathrm{Co}^{2+}$ groundwater plume is near $60 \mathrm{~m}$ downgradient from well 421 and at an elevation of $421.5 \mathrm{~m}$ with a maximum concentration of $0.00041 \mathrm{mmol} / \mathrm{L}$ (Figure 3.D). Field data show the center of mass in the $\mathrm{Co}^{2+}$ groundwater plume is near $0 \mathrm{~m}$ downgradient from well 421 and at an elevation of $422.5 \mathrm{~m}$ AMSL with a maximum concentration of $0.0004 \mathrm{mmol} / \mathrm{L}^{1}$ (Figure 3.C). 
A)

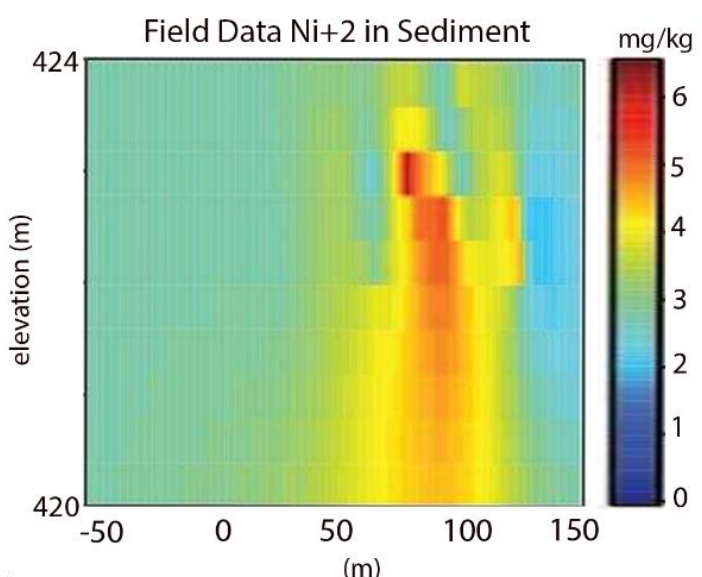

C)

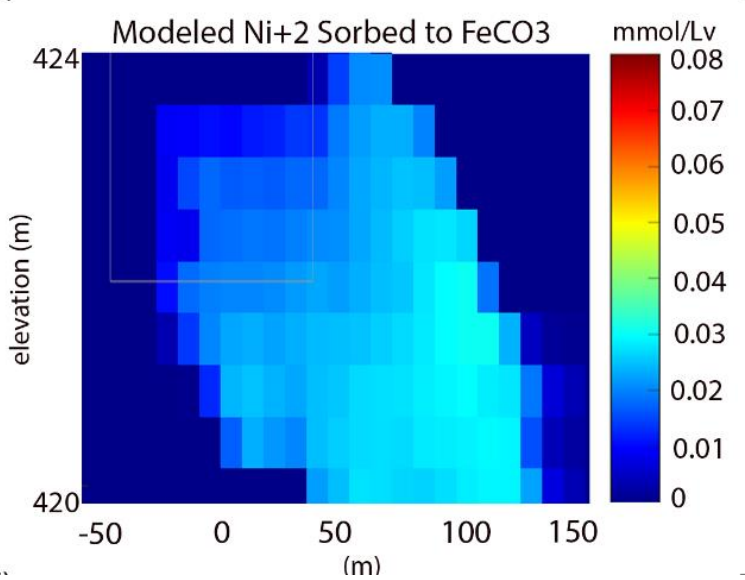

B)

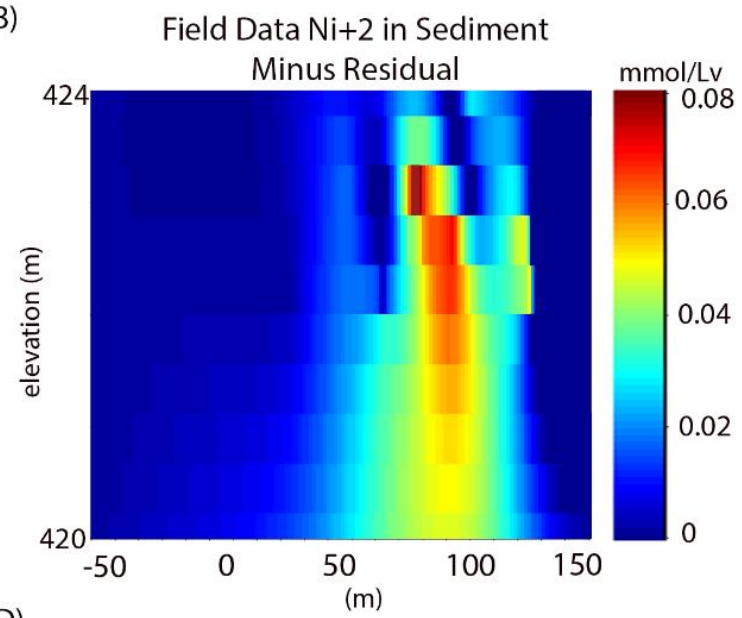

D)

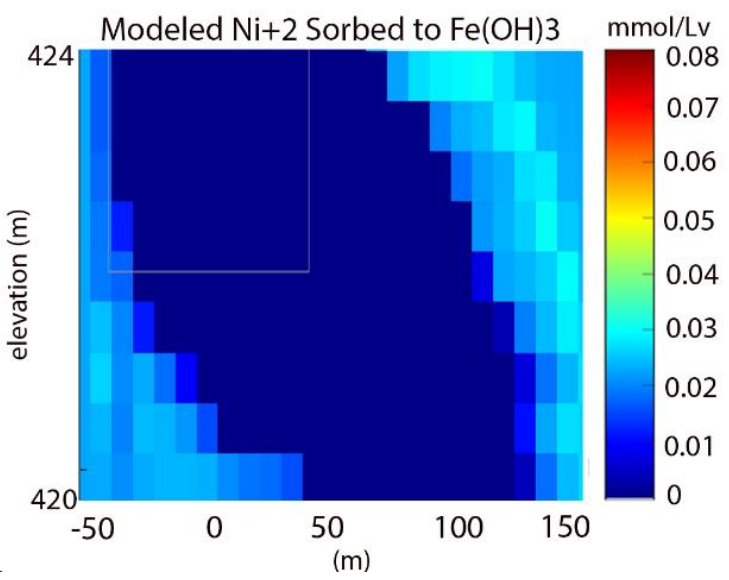

Figure 4 Measured and modeled $\mathrm{Ni}^{2+}$ in sediment. A) is a plot of interpolated field data of $\mathrm{Ni}^{2+}$ in sediment $(\mathrm{mg} / \mathrm{kg})$ from Jones. B) is a plot of interpolated field data of $\mathrm{Ni}^{2+}$ in sediment with the residual value of $2.75 \mathrm{mg} / \mathrm{kg}$ subtracted and data converted to the model units of $\mathrm{mmol} / \mathrm{L}_{\mathrm{v}}$. C) is a plot of modeled $\mathrm{Ni}^{2+}$ sorbed to $\mathrm{FeCO}_{3}$ in sediment $\left(\mathrm{mmol} / \mathrm{L}_{\mathrm{v}}\right)$. D) is a plot of modeled $\mathrm{Ni}^{2+}$ sorbed to $\mathrm{Fe}(\mathrm{OH})_{3}$ in sediment $\left(\mathrm{mmol} / \mathrm{L}_{\mathrm{v}}\right)$. 
A)
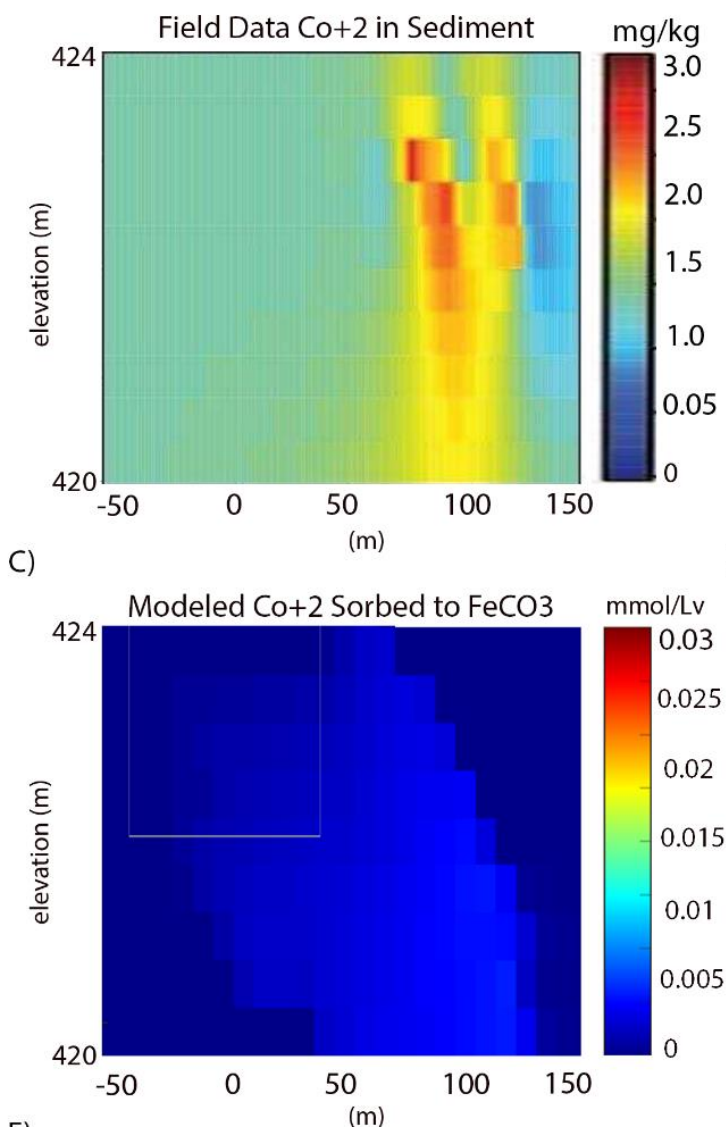

B)

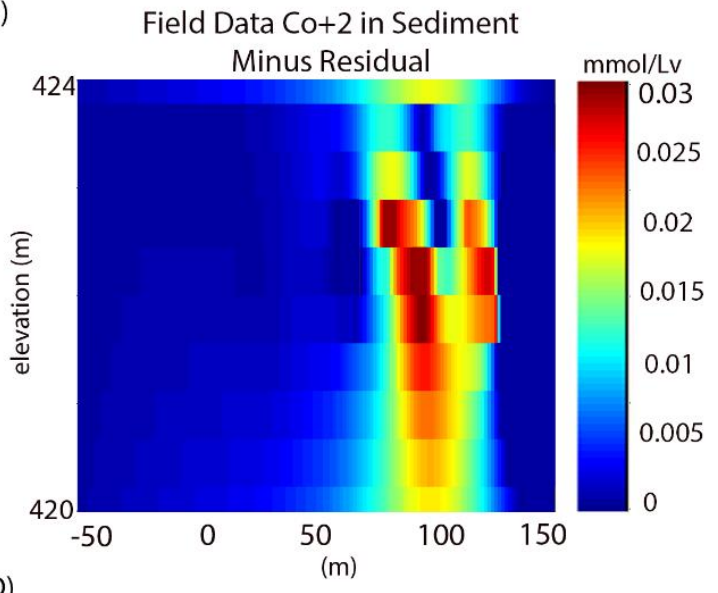

D)

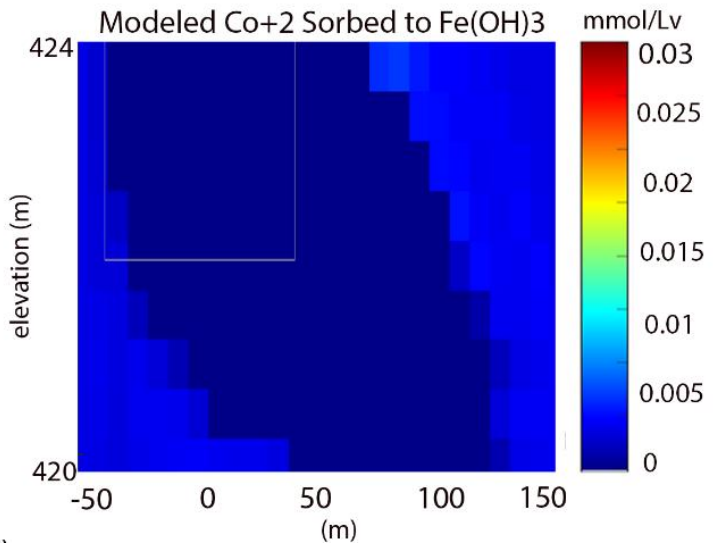

Figure 5 Measured and modeled $\mathrm{Co}^{2+}$ in sediment. A) is a plot of interpolated field data of $\mathrm{Co}^{2+}$ in sediment from Jones (2020). B) is a plot of interpolated field data of $\mathrm{Co}^{2+}$ in sediment with the residual value of $1.25 \mathrm{mg} / \mathrm{kg}$ subtracted. C) is a plot of modeled $\mathrm{Co}^{2+}$ sorbed to $\mathrm{FeCO}_{3}$ in sediment keeping a consistent color bar range with field data. D) is a plot of modeled $\mathrm{Co}^{2+}$ sorbed to $\mathrm{Fe}(\mathrm{OH})_{3}$ in sediment keeping a consistent color bar range with field data. E) is a plot of modeled $\mathrm{Co}^{2+}$ sorbed to $\mathrm{FeCO}_{3}$ in sediment with a unique color bar range to highlight the concentrations found in the aquifer. F) is a plot of modeled $\mathrm{Co}^{2+}$ sorbed to $\mathrm{FeCO}_{3}$ in sediment with a unique color bar range to highlight the concentrations found in the aquifer 
A)

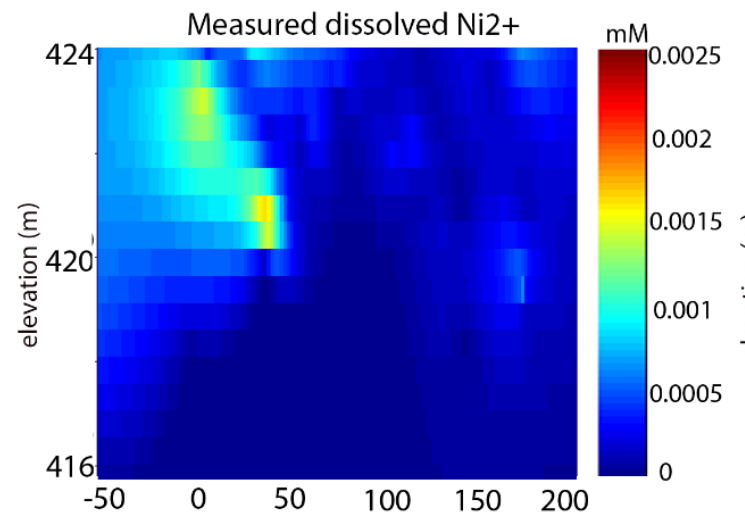

C)

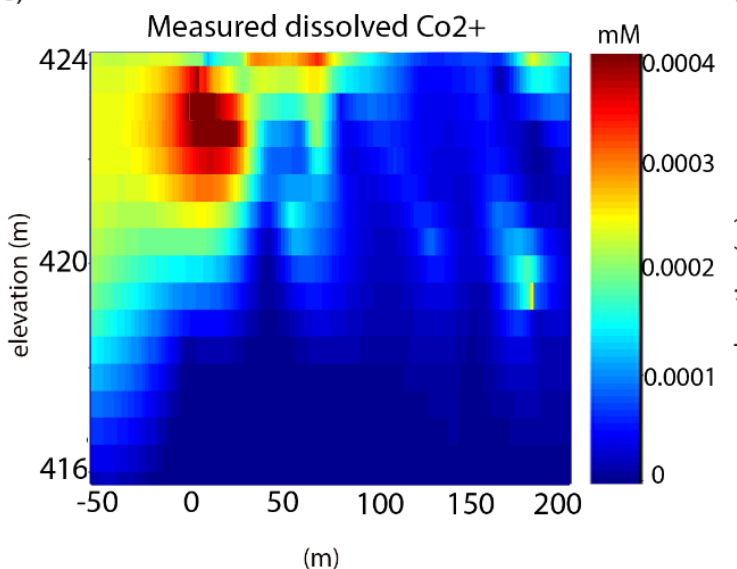

B)

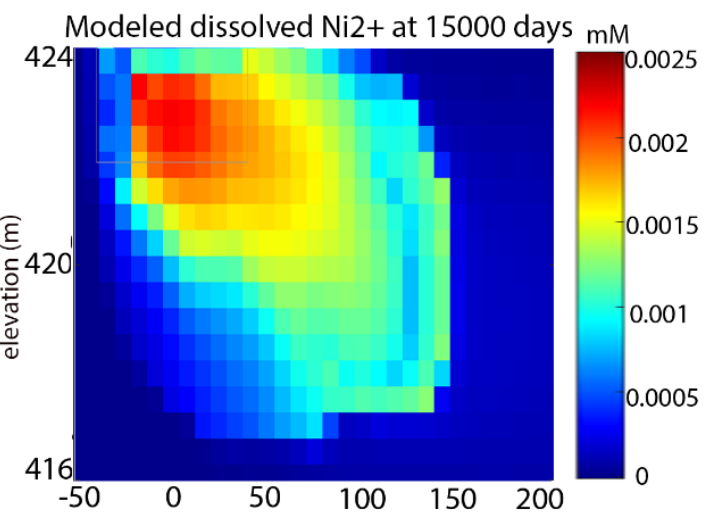

D)

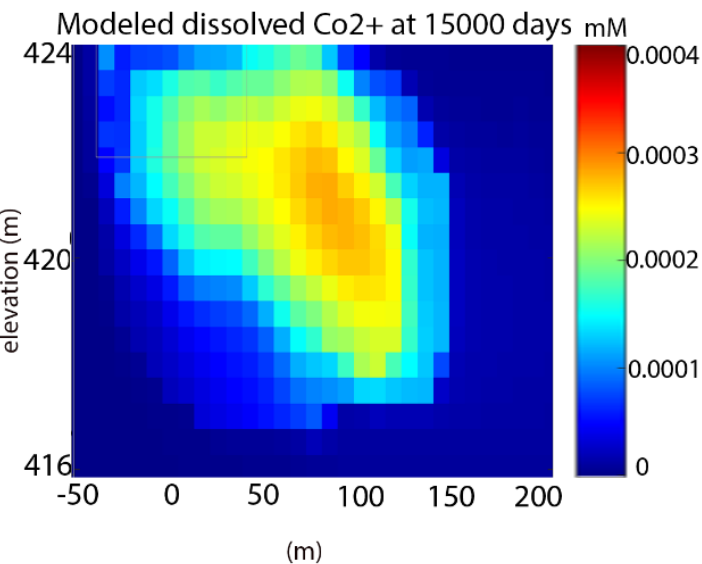

Figure 6. Mobilized trace elements measured from well sampling and modeled in this study. A) is a plot of interpolated measurements of aqueous $\mathrm{Ni}^{2+}(\mathrm{mM})$ in the aquifer from Jones $\left.{ }^{1} . \mathrm{B}\right)$ is a plot of modeled aqueous $\mathrm{Ni}^{2+}(\mathrm{mM})$ in the aquifer. C) is a plot of interpolated measurements of aqueous $\mathrm{Co}^{2+}(\mathrm{mM})$ in the aquifer from Jones $\left.{ }^{1} . \mathrm{D}\right)$ is a plot of modeled aqueous $\mathrm{Co}^{2+}(\mathrm{mM})$ in the aquifer.

From field sampling, Jones ${ }^{1}$ observed enrichment of of $\mathrm{Ni}^{2+}$ and $\mathrm{Co}^{2+}$ in sediment of the Fereducing zone and hypothesized that carbonates may be precipitating and sorbing cations. I was able to replicate this hypothesis in the model (Figure 3.F), lending support to Jones' hypothesis. 
Increased concentrations of aqueous $\mathrm{Fe}^{2+}$ and $\mathrm{HCO}_{3}^{-}$, a result of geochemical mechanisms described previously (Table 2), result in the precipitation of $\mathrm{FeCO}_{3}$, and at the $\mathrm{pH}$ values present in the Fe-reducing zone (Figure 3.D), $\mathrm{FeCO}_{3}$ generates a negative surface charge (Table 2) allowing $\mathrm{Ni}^{2+}$ and $\mathrm{Co}^{2+}$ to sorb onto siderite in the sediment. Thus at 15,000 days, $\mathrm{Ni}^{2+}$ and $\mathrm{Co}^{2+}$ are largely attenuated by sorption from $0-100 \mathrm{~m}$ downgradient from well 421 with the highest concentrations occurring in the Fe-reducing zone between $50-100 \mathrm{~m}$ downgradient from well 421 via this mechanism. The maximum concentrations of $\mathrm{Ni}^{2+}$ and $\mathrm{Co}^{2+}$ sorbed to $\mathrm{FeCO}_{3}$ at 15,000 days are $0.03 \mathrm{mmol} / \mathrm{L}_{\mathrm{v}}$ and $0.0041 \mathrm{mmol} / \mathrm{L}_{\mathrm{v}}$, respectively (Figures 4 and 5), and are slightly lower than concentrations seen in field data of $0.08 \mathrm{mmol} / \mathrm{L}_{\mathrm{v}}$ and $0.03 \mathrm{mmol} / \mathrm{L}_{\mathrm{v}}$, respectively ${ }^{1}$.

The model indicates a greater attenuation of $\mathrm{Ni}^{2+}$ and $\mathrm{Co}^{2+}$ via sorption to $\mathrm{FeCO}_{3}$ near the oil body than is observed in field data, perhaps because groundwater $\mathrm{pH}$ in the model is $\sim 0.5-0.75 \mathrm{pH}$ units higher than observed in groundwater near the oil, diminishing the effect of low $\mathrm{pH}$ inhibition of siderite precipitation (Eq. 1) while simultaneously increasing the relative abundance of negative surface sites able to sorb $\mathrm{Ni}^{2+}$ and $\mathrm{Co}^{2+}$. Regardless, the model demonstrates an overall depletion of $\mathrm{Ni}$ and $\mathrm{Co}$ concentrations in sediment in this region relative to background concentrations, consistent with the pattern observed from field sampling; both modeled data and field data reflect regions of high concentrations of $\mathrm{Ni}^{2+}$ and $\mathrm{Co}^{2+}$ in sediment in the Fe-reducing zone and at the leading edge of the plume, caused by the precipitation of $\mathrm{FeCO}_{3}$ and $\mathrm{Fe}(\mathrm{OH})_{3}$, respectively. Both of these minerals serve as sorbent phases for $\mathrm{Ni}^{2+}$ and $\mathrm{Co}^{2+}$ based on the $\mathrm{pH}$ in their respective zones.

Further downgradient where the aquifer transitions from anoxic Fe-reducing zone to suboxic conditions, groundwater is no longer supersaturated with respect to $\mathrm{FeCO}_{3}$, so its precipitation ceases (Figure 3.D). Additionally, the suboxic conditions result in the oxidizing of aqueous $\mathrm{Fe}^{2+}$ 
and precipitate $\mathrm{Fe}(\mathrm{OH})_{3}$, which in turn attenuates $\mathrm{Ni}^{2+}$ and $\mathrm{Co}^{2+}$ through sorption. At $\sim 125 \mathrm{~m}$ downgradient from well 421, a "wall" of elevated concentrations of $\mathrm{Ni}^{2+}$ and $\mathrm{Co}^{2+}$ sorbed to $\mathrm{Fe}(\mathrm{OH})_{3}$ in sediment occurs (Figures 4 and 5), because $\mathrm{Fe}(\mathrm{OH})_{3}$ is stable under the suboxic conditions and the $\mathrm{pH}$ allows for the formation of negatively charged surface sites. The maximum concentrations of $\mathrm{Ni}^{2+}$ and $\mathrm{Co}^{2+}$ sorbed to the wall of precipitated $\mathrm{Fe}(\mathrm{OH})_{3}$ at 15,000 days are 0.02 $\mathrm{mmol} / \mathrm{L}_{\mathrm{v}}$ and $0.003 \mathrm{mmol} / \mathrm{L}_{\mathrm{v}}$ respectively. The maximum concentrations $\mathrm{of}^{2+} \mathrm{in}^{2+}$ and $\mathrm{Co}^{2+}$ in sediment from field data are $0.08 \mathrm{mmol} / \mathrm{L}_{\mathrm{v}}$ and $0.03 \mathrm{mmol} / \mathrm{L}_{\mathrm{v}}$, respectively ${ }^{1}$.

\subsection{Discussion}

Concentrations and patterns in the model reflect the same general patterns observed in field data, but the model could not exactly match the field data due to the comprehensive modeling approach of simulating numerous parameters for $40+$ years of data with reasonable accuracy. The sediment concentrations can be more closely matched to field data using different $\log \mathrm{K}$ values, but this match occurs at the expense of not only groundwater concentrations but the location of the groundwater plume as well. Thus, a model that is not an exact match but is close to both sediment concentrations as well as groundwater plume location was considered accurate.

While extensive research of sorption parameters for $\mathrm{Fe}(\mathrm{OH})_{3}$ exist $^{54}$, this model illustrates the need for a better understanding of sorption parameters related to $\mathrm{FeCO}_{3}$, especially in contaminant plumes where Fe-reduction occurs. Some research has looked at the surface area and site density of $\mathrm{FeCO}_{3}{ }^{56,57}$ though these laboratory findings likely do not reflect the surface area of amorphous $\mathrm{FeCO}_{3}$ precipitates that form in a complex geochemical environment like the Bemidji contaminant plume. Little research has been done to determine sorption constants for $\mathrm{Ni}^{2+}$ or $\mathrm{Co}^{2+}$ sorption to siderite. A more robust understanding of sorption parameters for $\mathrm{FeCO}_{3}$ much like that of $\mathrm{Fe}(\mathrm{OH})_{3}$ is essential to better understand mobilization and attenuation of trace elements in crude-oil 
contaminated aquifers and more generally in aquifers with abundant bioavailable organic carbon that biodegrades via Fe-reduction.

Parameterizing $\mathrm{FeCO}_{3}$ is further complicated by the fact that the actual Fe carbonate phase has been difficult to characterize in the Bemidji aquifer. It has been particularly difficult to positively identify crystalline Fe-carbonates in sediment from the field (Ziegler, personal communication), likely due to its amorphous or poorly crystalline nature. This is congruent with expectations for recently precipitated $\mathrm{FeCO}_{3}$. Kohler et al. ${ }^{64}$ looked at two sediment cores from the Fe-reducing zone of Bemidji contaminant plume. Each of these cores contained $\mathrm{Fe}^{2+}$ attributed to ion exchangeable and/or carbonate reservoirs. By performing an extraction step that inhibits carbonate dissolution it was possible to determine the amount of $\mathrm{Fe}^{2+}$ from a reservoir other than ion exchange, possibly a carbonate reservoir such as siderite, ferroan calcite, or an amorphous phase. Because the carbonate phase(s) is not well characterized, it is difficult to determine model inputs for its mineral properties (i.e. surface area, surface side density, and reactivity).

There are multiple surface complexation models that can be used in a reactive transport model. Previous modeling studies have used the constant-capacitance model $^{65}$, the diffuse-layer model ${ }^{54}$, the triple-layer model ${ }^{66}$, and the charge distribution multisite surface complexation (CD-MUSIC) model ${ }^{67}$. The constant-capacitance model assumes a sorption mechanism of ligand exchange for anionic trace elements that sorb and form tightly bound inner-sphere complexes ${ }^{68}$. The diffuselayer model, also known as the double-layer model, assumes inner-sphere surface complexes are formed but also includes a diffuse layer formed by background electrolyte ions ${ }^{68}$. Surface complexation of $\mathrm{Fe}(\mathrm{OH})_{3}$ has been successfully modeled at the Bemidji aquifer ${ }^{69}$ with surface parameters from Dzombak and Morel $^{54}$ using the double-layer model thus the same was used in this model. The triple-layer model assumes inner-sphere complexation occurs as well as adsorption 
through an outer-sphere adsorption mechanism that results in weaker surface complexes ${ }^{68}$. The CD-MUSIC model assumes inner- and outer-sphere complexes are possible but also allows for various reactive surface groups including singly, doubly, and triply coordinated hydroxyl groups ${ }^{68}$. These more specific surface complexation models were considered for $\mathrm{FeCO}_{3}$ in this model. However, due to the lack of studies on surface parameters for $\mathrm{FeCO}_{3}$, these more specific models were determined to be over-parameterized for modeling trace element sorption to $\mathrm{FeCO}_{3}$ in this study.

Geogenic trace elements like $\mathrm{Ni}^{2+}$ and $\mathrm{Co}^{2+}$ commonly occur in aquifer solids, through sorption to Fe hydroxides. However, when bioavailable organic $\mathrm{C}$ is introduced into the system, biodegradation processes can result in the mobilization trace elements through Fe-reduction and create secondary trace element contaminant plumes. In the Bemidji aquifer, we observed this phenomenon with respect to $\mathrm{Ni}^{2+}$ and $\mathrm{Co}^{2+}$ while others have also observed the mobilization of $\mathrm{As}$ and $\mathrm{Ba}^{2+}$ and $\mathrm{Sr}^{2+}$. However, it is important to recognize that trace element mobilization is not limited to just these particular trace elements. In fact, the potential for trace element mobilization is dependent upon the trace elements originally sorbed to the Fe hydroxide in the aquifer matrix. For example, lead, cadmium, and mercury were non-detectable in uncontaminated sediments in the Bemidji aquifer, therefore they likely would not pose a groundwater threat. However, it is possible that an aquifer with higher levels of naturally occurring lead, cadmium, or mercury in sediment is vulnerable to unsafe groundwater concentrations of these toxic elements if reducing conditions are established.

Complex mixtures of trace elements in groundwater can have unique ecological health consequences and human health impacts via drinking water. In the contaminated portion of the Bemidji aquifer, aqueous $\mathrm{Ni}^{2+}$ exceeds regulatory limits. Excess $\mathrm{Ni}^{2+}$ has been linked to skin 
irritation $^{21}$. Though $\mathrm{Co}^{2+}$ is not currently regulated by the EPA, it is under consideration due to its possible public health concerns ${ }^{23}$. Furthermore, more research is needed to understand the combined toxicology of simultaneous exposure to benzene, $\mathrm{Ni}^{2+}, \mathrm{Co}^{2+}$, and other mobilized trace elements ${ }^{70}$. This model underscores the importance of monitoring not only organic contaminants at crude-oil spill sites but inorganic contaminant, and particularly trace elements, as well.

\section{Conclusion}

This model describes the geochemical processes behind mobilization and attenuation of geogenic trace elements triggered by biodegradation processes. Reducing conditions in the aquifer lead to biodegradation coupled with Fe-reduction which causes the dissolution of $\mathrm{Fe}(\mathrm{OH})_{3}$ and mobilizes trace elements such as $\mathrm{Ni}^{2+}$ and $\mathrm{Co}^{2+}$ that were previously sorbed to $\mathrm{Fe}(\mathrm{OH})_{3}$ in the aquifer matrix. Within the active Fe-reducing zone groundwater becomes saturated with respect to $\mathrm{FeCO}_{3}$ leading to its precipitation. Given the conditions of the aquifer where $\mathrm{FeCO}_{3}$ precipitates, it generates a negative surface charge and thus is capable of attenuating previously mobilized cations while allowing mobilized oxyanions (such as As) to remain in groundwater. Downgradient, conditions are no longer favorable for siderite but are favorable for the precipitation of $\mathrm{Fe}(\mathrm{OH})_{3}$, allowing for the sorption of both cations and oxyanions including $\mathrm{Ni}^{2+}, \mathrm{Co}^{2+}$, and $\mathrm{As}$ based on its simultaneous positively and negatively charged surface sites. Conditions in the active Fe-reducing zone which allow for the precipitation and negative surface charge of $\mathrm{FeCO}_{3}$ can, in part, account for the similarities in $\mathrm{Ni}^{2+}$ and $\mathrm{Co}^{2+}$ attenuation patterns in the aquifer as well as the differences in $\mathrm{Ni}^{2+} / \mathrm{Co}^{2+}$ and As attenuation patterns in the aquifer. This modeling study highlights the importance in expanding our knowledge of $\mathrm{FeCO}_{3}$ sorption parameters as well as the importance of monitoring inorganic contaminants, specifically trace elements, at organic contaminant sites. 


\section{Acknowledgements}

I would like to thank Gene-Hua Crystal $\mathrm{Ng}$, who provided valuable insights into the robust Bemidji site model that was adapted in this study. I would also like to thank Isabelle Cozzarelli, who offered insight into trace-element cycling in the aquifer. I am grateful to Kurt Knesel for his insightful comments and suggestions on earlier drafts of this thesis. Finally, I would like to express special thanks to Brady Ziegler for advising me on this thesis project.

\section{References}

(1) Jones, K. L. Trace Element Cycling in Crude-Oil-Contaminated Aquifer near Bemidji, Northern Minnesota., Trinity University, San Antonio, TX, 2020.

(2) Toccalino, P. L.; Hopple, J. A. The Quality of Our Nation's Waters-Quality of Water from Public-Supply Wells in the United States, 1993-2007-Overview of Major Findings: U.S. Geological Survey Circular 1346; 2010.

(3) Zachara, J. M.; Fredrickson, J. K.; Smith, S. C.; Gassman, P. L. Solubilization of Fe (III) Oxide-Bound Trace Metals by a Dissimilatory Fe (III) Reducing Bacterium. Geochimica et Cosmochimica Acta 2001, 65 (1), 75-93.

(4) Buschmann, J.; Berg, M.; Stengel, C.; Winkel, L.; Sampson, M. L.; Trang, P. T. K.; Viet, P. H. Contamination of Drinking Water Resources in the Mekong Delta Floodplains: Arsenic and Other Trace Metals Pose Serious Health Risks to Population. Environment International 2008, 34 (6), 756-764.

(5) Nickson, R.; McArthur, J.; Burgess, W.; Ahmed, K. M.; Ravenscroft, P.; Rahmanñ, M. Arsenic Poisoning of Bangladesh Groundwater. Nature 1998, 395 (6700), 338.

(6) Kjøller, C.; Postma, D.; Larsen, F. Groundwater Acidification and the Mobilization of Trace Metals in a Sandy Aquifer. Environmental science \& technology 2004, 38 (10), 28292835 .

(7) Yang, J. Y.; Yang, X. E.; He, Z. L.; Li, T. Q.; Shentu, J. L.; Stoffella, P. J. Effects of PH, Organic Acids, and Inorganic Ions on Lead Desorption from Soils. Environmental Pollution 2006, 143 (1), 9-15.

(8) Houben, G. J.; Sitnikova, M. A.; Post, V. E. A. Terrestrial Sedimentary Pyrites as a Potential Source of Trace Metal Release to Groundwater-A Case Study from the Emsland, Germany. Applied Geochemistry 2017, 76, 99-111. 
(9) Zhang, Y.-C.; Slomp, C. P.; Broers, H. P.; Passier, H. F.; van Cappellen, P. Denitrification Coupled to Pyrite Oxidation and Changes in Groundwater Quality in a Shallow Sandy Aquifer. Geochimica et Cosmochimica Acta 2009, 73 (22), 6716-6726.

(10) Schreiber, M. E.; Simo, J. A.; Freiberg, P. G. Stratigraphic and Geochemical Controls on Naturally Occurring Arsenic in Groundwater, Eastern Wisconsin, USA. Hydrogeology Journal 2000, 8 (2), 161-176.

(11) Aksoy, N.; Şimşek, C.; Gunduz, O. Groundwater Contamination Mechanism in a Geothermal Field: A Case Study of Balcova, Turkey. Journal of Contaminant Hydrology 2009, 103 (1-2), 13-28.

(12) Morales, I.; Villanueva-Estrada, R. E.; Rodríguez, R.; Armienta, M. A. Geological, Hydrogeological, and Geothermal Factors Associated to the Origin of Arsenic, Fluoride, and Groundwater Temperature in a Volcanic Environment "El Bajío Guanajuatense", Mexico. Environmental Earth Sciences 2015, 74 (6), 5403-5415.

(13) Brammer, H.; Ravenscroft, P. Arsenic in Groundwater: A Threat to Sustainable Agriculture in South and South-East Asia. Environment International 2009, 35 (3), 647654. https://doi.org/https://doi.org/10.1016/j.envint.2008.10.004.

(14) Cozzarelli, I. M.; Schreiber, M. E.; Erickson, M. L.; Ziegler, B. A. Arsenic Cycling in Hydrocarbon Plumes: Secondary Effects of Natural Attenuation. Groundwater 2016, 54 (1), 35-45. https://doi.org/10.1111/gwat.12316.

(15) Ziegler, B. A.; Schreiber, M. E.; Cozzarelli, I. M.; Crystal Ng, G.-H. A Mass Balance Approach to Investigate Arsenic Cycling in a Petroleum Plume. Environmental Pollution 2017, 231, 1351-1361. https://doi.org/https://doi.org/10.1016/j.envpol.2017.08.110.

(16) Ziegler, B. A.; Schreiber, M. E.; Cozzarelli, I. M. The Role of Alluvial Aquifer Sediments in Attenuating a Dissolved Arsenic Plume. Journal of Contaminant Hydrology 2017, 204, 90-101. https://doi.org/https://doi.org/10.1016/j.jconhyd.2017.04.009.

(17) Amirbahman, A.; Kent, D. B.; Curtis, G. P.; Davis, J. A. Kinetics of Sorption and Abiotic Oxidation of Arsenic(III) by Aquifer Materials. Geochimica et Cosmochimica Acta 2006, 70 (3), 533-547. https://doi.org/https://doi.org/10.1016/j.gca.2005.10.036.

(18) Delemos, J. L.; Bostick, B. C.; Renshaw, C. E.; StÜrup, S.; Feng, X. Landfill-Stimulated Iron Reduction and Arsenic Release at the Coakley Superfund Site (NH). Environmental science \& technology 2006, 40 (1), 67-73.

(19) Ziegler, B. A.; McGuire, J. T.; Cozzarelli, I. M. Rates of As and Trace-Element Mobilization Caused by Fe Reduction in Mixed BTEX-Ethanol Experimental Plumes. Environmental Science \& Technology 2015, 49 (22), 13179-13189. https://doi.org/10.1021/acs.est.5b02341.

(20) Kravchenko, J.; Darrah, T. H.; Miller, R. K.; Lyerly, H. K.; Vengosh, A. A Review of the Health Impacts of Barium from Natural and Anthropogenic Exposure. Environmental 
Geochemistry and Health 2014, 36 (4), 797-814. https://doi.org/10.1007/s10653-0149622-7.

(21) Nielsen, G. D.; Søderberg, U.; Jørgensen, P. J.; Templeton, D. M.; Rasmussen, S. N.; Andersen, K. E.; Grandjean, P. Absorption and Retention of Nickel from Drinking Water in Relation to Food Intake and Nickel Sensitivity. Toxicology and Applied Pharmacology 1999, 154 (1), 67-75. https://doi.org/https://doi.org/10.1006/taap.1998.8577.

(22) Smith, A. H.; Hopenhayn-Rich, C.; Bates, M. N.; Goeden, H. M.; Hertz-Picciotto, I.; Duggan, H. M.; Wood, R.; Kosnett, M. J.; Smith, M. T. Cancer Risks from Arsenic in Drinking Water. Environmental Health Perspectives 1992, 97, 259-267. https://doi.org/10.1289/ehp.9297259.

(23) US EPA, O. Announcement of Preliminary Regulatory Determinations for Contaminants on the Fourth Drinking Water Contaminant Candidate List. 2020.

(24) Baedecker, M. J.; Cozzarelli, I. M.; Eganhouse, R. P.; Siegel, D. I.; Bennett, P. C. Crude Oil in a Shallow Sand and Gravel Aquifer-III. Biogeochemical Reactions and Mass Balance Modeling in Anoxic Groundwater. Applied Geochemistry 1993, 8 (6), 569-586. https://doi.org/https://doi.org/10.1016/0883-2927(93)90014-8.

(25) Bennett, P. C.; Siegel, D. E.; Baedecker, M. J.; M.F., H. Crude Oil in a Shallow Sand and Gravel Aquifer-I. Hydrogeology and Inorganic Geochemistry. Applied Geochemistry 1993, 8 (6), 529-549. https://doi.org/https://doi.org/10.1016/0883-2927(93)90012-6.

(26) Hult, M. F.; (U.S.), G. S. Ground-Water Contamination by Crude Oil at the Bemidji, Minnesota, Research Site: U.S. Geological Survey Toxic Waste--Ground-Water Contamination Study: Papers Presented at the Toxic-Waste Technical Meeting, Tucson, Arizona, March 20-22, 1984; Ground-water Contamination by Crude Oil at the Bemidji, Minnesota, Research Site: U.S. Geological Survey Toxic Waste--ground-water Contamination Study: Papers Presented at the Toxic-Waste Technical Meeting, Tucson, Arizona, March 20-22, 1984; U.S. Geological Survey, 1984.

(27) Essaid, H.; Bekins, B.; Herkelrath, W.; Delin, G. Crude Oil at the Bemidji Site: 25 Years of Monitoring, Modeling, and Understanding. Ground water 2009, 49, 706-726. https://doi.org/10.1111/j.1745-6584.2009.00654.x.

(28) Ng, G.-H. C.; Bekins, B. A.; Cozzarelli, I. M.; Baedecker, M. J.; Bennett, P. C.; Amos, R. T. A Mass Balance Approach to Investigating Geochemical Controls on Secondary Water Quality Impacts at a Crude Oil Spill Site near Bemidji, MN. Journal of Contaminant Hydrology 2014, 164, 1-15. https://doi.org/https://doi.org/10.1016/j.jconhyd.2014.04.006.

(29) Ng, G.-H. C.; Bekins, B. A.; Cozzarelli, I. M.; Baedecker, M. J.; Bennett, P. C.; Amos, R. T.; Herkelrath, W. N. Reactive Transport Modeling of Geochemical Controls on Secondary Water Quality Impacts at a Crude Oil Spill Site near Bemidji, MN. Water Resources Research 2015, 51 (6), 4156-4183. https://doi.org/https://doi.org/10.1002/2015WR016964. 
(30) Cozzarelli, I. M.; Schreiber, M. E.; Erickson, M. L.; Ziegler, B. A. Arsenic Cycling in Hydrocarbon Plumes: Secondary Effects of Natural Attenuation. Groundwater 2016, 54 (1), 35-45. https://doi.org/10.1111/gwat.12316.

(31) Essaid, H. I.; Bekins, B. A.; Godsy, E. M.; Warren, E.; Baedecker, M. J.; Cozzarelli, I. M. Simulation of Aerobic and Anaerobic Biodegradation Processes at a Crude Oil Spill Site. Water Resources Research 1995, 31 (12), 3309-3327.

(32) Essaid, H. I.; Cozzarelli, I. M.; Eganhouse, R. P.; Herkelrath, W. N.; Bekins, B. A.; Delin, G. N. Inverse Modeling of BTEX Dissolution and Biodegradation at the Bemidji, MN Crude-Oil Spill Site. Journal of Contaminant Hydrology 2003, 67 (1), 269-299. https://doi.org/https://doi.org/10.1016/S0169-7722(03)00034-2.

(33) Amos, R. T.; Ulrich Mayer, K. Investigating the Role of Gas Bubble Formation and Entrapment in Contaminated Aquifers: Reactive Transport Modelling. Journal of $\begin{array}{llllll}\text { Contaminant Hydrology } & \text { 2006, } & 87 & \text { (1), }\end{array}$ https://doi.org/https://doi.org/10.1016/j.jconhyd.2006.04.008.

(34) Curtis, G. P.; Cozzarelli, I. M.; Baedecker, M. J.; Bekins, B. A. Coupled Biogeochemical Modeling of Ground Water Contamination at the Bemidji Minnesota Crude Oil Spill Site. US Geological Survey Toxic Substances Hydrology Program Proceedings 1999, 153-158.

(35) Curtis, G. P. Comparison of Approaches for Simulating Reactive Solute Transport Involving Organic Degradation Reactions by Multiple Terminal Electron Acceptors. Computers \& Geosciences 2003, 29 (3), 319-329.

(36) Prommer, H.; Barry, D. A.; Zheng, C. MODFLOW/MT3DMS-Based Reactive Multicomponent Transport Modeling. Groundwater 2003, 41 (2), 247-257. https://doi.org/https://doi.org/10.1111/j.1745-6584.2003.tb02588.x.

(37) Parkhurst, D. L.; Appelo, C. A. J. USER'S GUIDE TO PHREEQC (VERSION 2)-A COMPUTER PROGRAM FOR SPECIATION, BATCH-REACTION, ONE-DIMENSIONAL TRANSPORT, AND INVERSE GEOCHEMICAL CALCULATIONS; Denver, Co, 1999.

(38) Harbaugh, A. W. MODFLOW-2005, The U.S. Geological Survey Modular Ground-Water Model-the Ground-Water Flow 2005. https://doi.org/https://doi.org/10.3133/tm6A16.

(39) Zheng, C.; Wang, P. P. MT3DMS: A Modular Three-Dimensional Multispecies Transport Model for Simulation of Advection, Dispersion, and Chemical Reactions of Contaminants in Groundwater Systems; Documentation and User's Guide; 1999.

(40) Dillard, L. A.; Essaid, H. I.; Herkelrath, W. N. Multiphase Flow Modeling of a Crude-Oil Spill Site with a Bimodal Permeability Distribution. Water Resources Research 1997, 33 (7), 1617-1632. https://doi.org/10.1029/97WR00857.

(41) Strobel, M. L.; Delin, G. N.; Munson, C. J. Spatial Variation in Saturated Hydraulic Conductivity of Sediments at a Crude-Oil Spill Site near Bemidji, Minnesota; US Department of the Interior, US Geological Survey, 1998; Vol. 98. 
(42) Eganhouse, R. P.; Baedecker, M. J.; Cozzarelli, I. M.; Aiken, G. R.; Thorn, K. A.; Dorsey, T. F. Crude Oil in a Shallow Sand and Gravel Aquifer-II. Organic Geochemistry. Applied Geochemistry 1993, 8 (6), 551-567. https://doi.org/https://doi.org/10.1016/08832927(93)90013-7.

(43) Baedecker, M. J.; Eganhouse, R. P.; Bekins, B. A.; Delin, G. N. Loss of Volatile Hydrocarbons from an LNAPL Oil Source. Journal of contaminant hydrology 2011, 126 (3-4), 140-152.

(44) Thorn, K. A.; Aiken, G. R. Biodegradation of Crude Oil into Nonvolatile Organic Acids in a Contaminated Aquifer near Bemidji, Minnesota. Organic Geochemistry 1998, 29 (4), 909-931.

(45) Tuccillo, M. E.; Cozzarelli, I. M.; Herman, J. S. Iron Reduction in the Sediments of a Hydrocarbon-Contaminated Aquifer. Applied Geochemistry 1999, 14 (5), 655-667. https://doi.org/https://doi.org/10.1016/S0883-2927(98)00089-4.

(46) Cozzarelli, I. M.; Bekins, B. A.; Baedecker, M. J.; Aiken, G. R.; Eganhouse, R. P.; Tuccillo, M. E. Progression of Natural Attenuation Processes at a Crude-Oil Spill Site: I. Geochemical Evolution of the Plume. Journal of Contaminant Hydrology 2001, 53 (3), 369-385. https://doi.org/https://doi.org/10.1016/S0169-7722(01)00174-7.

(47) Amos, R. T.; Bekins, B. A.; Cozzarelli, I. M.; Voytek, M. A.; Kirshtein, J. D.; Jones, E. J. P.; Blowes, D. W. Evidence for Iron-mediated Anaerobic Methane Oxidation in a Crude Oil-contaminated Aquifer. Geobiology 2012, 10 (6), 506-517.

(48) Amos, R. T.; Bekins, B. A.; Delin, G. N.; Cozzarelli, I. M.; Blowes, D. W.; Kirshtein, J. D. Methane Oxidation in a Crude Oil Contaminated Aquifer: Delineation of Aerobic Reactions at the Plume Fringes. Journal of contaminant hydrology 2011, 125 (1-4), 13-25.

(49) Amos, R. T.; Bekins, B. A.; Cozzarellli, I. M.; Voytek, M. A.; Kirshtein, J.; Delin, G. N.; Blowes, D. W. Methane Oxidation in a Crude Oil Contaminated Aquifer. Geochimica et Cosmochimica Acta Supplement 2008, 72 (12), A20.

(50) Sihota, N. J.; Singurindy, O.; Mayer, K. U. CO2-Efflux Measurements for Evaluating Source Zone Natural Attenuation Rates in a Petroleum Hydrocarbon Contaminated Aquifer. Environmental Science \& Technology 2011, 45 (2), 482-488.

(51) Sihota, N. J. J. Novel Approaches for Quantifying Source Zone Natural Attenuation of Fossil and Alternative Fuels. University of British Columbia 2014.

(52) Bekins, B. A.; Hostettler, F. D.; Herkelrath, W. N.; Delin, G. N.; Warren, E.; Essaid, H. I. Progression of Methanogenic Degradation of Crude Oil in the Subsurface. Environmental Geosciences 2005, 12 (2), 139-152.

(53) Jakobsen, R.; Postma, D. Redox Zoning, Rates of Sulfate Reduction and Interactions with Fe-Reduction and Methanogenesis in a Shallow Sandy Aquifer, Rømø, Denmark. Geochimica et Cosmochimica Acta 1999, 63 (1), 137-151. 
(54) Dzombak, D. A.; Morel, F. M. M. Surface Complexation Modeling: Hydrous Ferric Oxide; A Wiley-Interscience publication; Wiley, 1990.

(55) Tahervand, S.; Jalali, M. Sorption and Desorption of Potentially Toxic Metals (Cd, Cu, $\mathrm{Ni}$ and Zn) by Soil Amended with Bentonite, Calcite and Zeolite as a Function of PH. Journal of Geochemical Exploration 2017, 181, 148-159.

(56) Guo, H.; Ben, D.; Berner, Z. Removal of Arsenic from Aqueous Solution by Natural Siderite and Hematite. Applied Geochemistry - APPL GEOCHEM 2007, 22. https://doi.org/10.1016/j.apgeochem.2007.01.004.

(57) van Cappellen, P.; Charlet, L.; Stumm, W.; Wersin, P. A Surface Complexation Model of the Carbonate Mineral-Aqueous Solution Interface. Geochimica et Cosmochimica Acta 1993, 57 (15), 3505-3518. https://doi.org/https://doi.org/10.1016/0016-7037(93)90135-J.

(58) Zachara, J. M.; Cowan, C. E.; Resch, C. T. Sorption of Divalent Metals on Calcite. Geochimica et cosmochimica acta 1991, 55 (6), 1549-1562.

(59) Schreiber, M. E.; Simo, J. A.; Freiberg, P. G. Stratigraphic and Geochemical Controls on Naturally Occurring Arsenic in Groundwater, Eastern Wisconsin, USA. Hydrogeology Journal 2000, 8 (2), 161-176.

(60) Erickson, M. L.; Malenda, H. F.; Berquist, E. C.; Ayotte, J. D. Arsenic Concentrations after Drinking Water Well Installation: Time-Varying Effects on Arsenic Mobilization. Science of the Total Environment 2019, 678, 681-691.

(61) Erickson, M. L.; Barnes, R. J. Arsenic Concentration Variability in Public Water System Wells in Minnesota, USA. Applied Geochemistry 2006, 21 (2), 305-317.

(62) Barcelona, by M.; Puls, R.; Kaminski, D. Ground Water Purging and Sampling Methods: History vs. Hysteria; 2005.

(63) Langmuir, D. Aqueous Environmental Geochemistry; 1997.

(64) Kohler, M.; Kent, D. B.; Cozzarelli, I. M.; Elzings, E.; Scheiderich, K.; Bekins, B. A. Chemical Forms of Sediment-Bound Fe(II) in Sediments from an Aquifer Contaminated by a Petroleum Spill; 2018.

(65) Stumm, W.; Kummert, R.; Sigg, L. A Ligand Exchange Model for the Adsorption of Inorganic and Organic Ligands at Hydrous Oxide Interfaces. Croatica chemica acta 1980, $53(2), 291-312$.

(66) Davis, J. A.; Leckie, J. O. Surface Ionization and Complexation at the Oxide/Water Interface II. Surface Properties of Amorphous Iron Oxyhydroxide and Adsorption of Metal Ions. Journal of colloid and interface science 1978, 67 (1), 90-107.

(67) Hiemstra, T.; van Riemsdijk, W. H. A Surface Structural Approach to Ion Adsorption: The Charge Distribution (CD) Model. Journal of colloid and interface science 1996, 179 (2), 488-508. 
(68) Deverel, S. J.; Fujii, R. Chemistry of Trace Elements in Soils and Ground Water. Agricultural Salinity Assessment and Management. American Society of Civil Engineers, New York 1990, 64-90.

(69) Ziegler, B. A.; Ng, G. H.-C.; Cozzarelli, I. M.; Dunshee, A. J.; Schreiber, M. E. A Reactive Transport Model of Arsenic Cycling in a Petroleum-Contaminated Aquifer. Water 2021, 13.

(70) McGuire, J. T.; Cozzarelli, I. M.; Bekins, B. A.; Link, H.; Martinović-Weigelt, D. Toxicity Assessment of Groundwater Contaminated by Petroleum Hydrocarbons at a WellCharacterized, Aged, Crude Oil Release Site. Environmental Science \& Technology 2018, 52 (21), 12172-12178. https://doi.org/10.1021/acs.est.8b03657. 